\title{
Morphological and compositional study of quartz and cassiterite of the Mocambo Granite, South Pará Tin Province, Amazonian Craton
}

\author{
Rubem Santa Brígida Barros Neto ${ }^{1,2 *}\left(\mathbb{D}\right.$, Claudio Nery Lamarão ${ }^{1,2,3}\left(\mathbb{D}\right.$, Gisele Tavares Marques ${ }^{1,2,3}(\mathbb{D}$, \\ Cristina Valle Pinto-Coelho ${ }^{4}$ (D)
}

\begin{abstract}
Quartz and cassiterite crystals of granite, greisens, and quartz veins from Mocambo Granite, Carajás Province, were studied by scanning electron microscopy - cathodoluminescence and electron microprobe. Five types of quartz were identified: Qz1, magmatic and Qz2, Qz3, Qz4, and Qz5 hydrothermal. Qz1, anhedric to subhedric, luminescent and fractured at different intensities, predominating in less evolved rocks. Qz2, with low luminescence, is younger than Qz1; it occurs as irregular patches, filling fractures or forming veins that cut Qz1. Qz3, non-luminescent, resulting from continuous alteration, dissolution, and recrystallization processes; fills fractures that cut Qz1 and Qz2. Qz4 occurs in the most evolved and hydrothermalized rocks and in greisens bodies mineralized in cassiterite; is euhedral to subhedral, exhibits well-defined zoning, and has been interpreted as later than the previous one. Qz5 has poor luminescence; occurs in mineralized veins with wolframite and, secondarily, cassiterite. Qz1 shows Ti enrichment, while Qz4 associated with cassiterite is enriched with Al. Well-formed cassiterite crystals exhibit concentric zoning and low $\mathrm{Fe}, \mathrm{Ti}, \mathrm{W}, \mathrm{Nb}$ and $\mathrm{Mn}$ contents. Qz5-associated cassiterite crystals form inclusions in the wolframite, suggesting that cassiterite and wolframite precipitated from hydrothermal processes at different times.
\end{abstract}

KEYWORDS: Amazonian craton; SEM-CL images quartz textures; hydrothermal alteration; Tin mineralization; cassiterite.

\section{INTRODUCTION}

Morphological and textural studies of quartz by scanning electron microscopy cathodoluminescence (SEM-CL) and compositional analysis using an electron microprobe (EMP) and laser ablation inductively coupled plasma mass spectroscopy (LA-ICP-MS) have become important geological tools in identifying different quartz generations from the same magmatic body, revealing the evolution and crystallization conditions of magmas, mixing processes, deformation stages, zoning patterns, and intracrystalline defects. They can also detect and characterize hydrothermal quartz and its possible relationship with associated mineralizations (D'Lemos et al. 1997, Müller et al. 2000, 2003, 2005, 2018, Rusk and Reed 2002, Rusk et al. 2006, 2008, Wiebe et al. 2007, Breiter and Müller 2009, Larsen

\footnotetext{
${ }^{1}$ Programa de Pós-Graduação em Geologia e Geoquímica, Instituto de Geociências, Universidade Federal do Pará - Belém (PA), Brazil. E-mails: rubembarrosnt@gmail.com, lamarao@ufpa.br, gisele.ufpa@gmail.com

${ }^{2}$ Grupo de Pesquisa Petrologia de Granitoides, Universidade Federal do Pará - Belém (PA), Brazil.

${ }^{3}$ Laboratório de Microanálises, Universidade Federal do Pará - Belém (PA), Brazil.

${ }^{4}$ Programa de Pós-Graduação em Geologia, Universidade Federal do Paraná - Curitiba (PR), Brazil. E-mail: cristinavpc@ufpr.br

${ }^{*}$ Corresponding author.
}

C) 2020 The authors. This is an open access article distributed under the terms of the Creative Commons license. et al. 2009, Vasyukova et al. 2013, Lamarão et al. 2013, 2014, Sotero et al. 2015, Breiter et al. 2013, 2017).

Despite the advances made over the last twenty years, morphological-textural and compositional studies of quartz for petrological and metallogenetic purposes in South America are still rare. The first studies are recent, such as those by Lamarão et al. $(2013,2014)$, who showed that quartz is an excellent marker of the magmatic evolution and hydrothermal alterations that acted on mineralized granites of the Amazonian Craton (North of Brazil) and sandstones of the Parnaíba Basin (Northeast of Brazil), with quartz veins containing orange opal.

The Velho Guilherme Intrusive Suite (VGIS), located in the Carajás Province, Amazonian Craton, is composed of several anorogenic granite plutons affected by hydrothermal processes at different intensities, commonly mineralized in tin and other rare metals (Abreu and Ramos 1974, Teixeira et al. 2002, 2005, Lamarão et al. 2012). Granites in this suite are, therefore, a good target for morphological and compositional studies of the different types of quartz and associated mineralization.

The present study involved SEM-CL and EMP analyses of quartz and cassiterite crystals from the Mocambo Granite, in the VGIS. The main objective of this work was to morphologically, texturally, and compositionally characterize quartz crystals and to correlate them with the intensity of the hydrothermal alteration and mineralization present in rocks and greisen bodies, in addition to characterizing the morphology and composition of cassiterite crystals. 


\section{GEOLOGICAL ASPECTS OF VELHO GUILHERME INTRUSIVE SUITE}

The Carajás Province, considered the best-preserved Archean nucleus of the Amazonian Craton (Almeida et al. 1981), is divided into two major tectonic domains (Santos et al. 2003, Vasquez et al. 2008): the Mesoarchean Rio Maria Domain, which is the most widely studied, and the Mesoarchean to Neoarchean Carajás Domain, which is less geologically known.

During the Paleoproterozoic, the Rio Maria Domain underwent extensive anorogenic granite magmatism (Fig. 1), represented by granite plutons and batholiths of the Jamon (SJ), Serra dos Carajás (SSC) and Velho Guilherme (VGIS) suites and contemporary felsic to mafic dykes (Dall'Agnol et al. 2006, Almeida et al. 2006). In the São Félix do Xingu region, in the eastern portion of the Rio Maria Domain, anorogenic magmatism is represented by VGIS granites, formed by the Antonio Vicente, Benedita, Ubim/Sul, Serra da Queimada, Rio Xingu, Velho Guilherme, Bom Jardim, and Mocambo plutons, mineralized in cassiterite, fluorite, topaz, columbite-tantalite, molybdenite, and wolframite. Alkali feldspar granites and syenogranites predominate, with subordinate peraluminous to metaluminous monzogranites affected by late- to post-magmatic alteration of varying intensities (Dall'Agnol et al. 1993, Teixeira et al. 2002, 2005, Lamarão et al. 2012). These granites show subalkaline

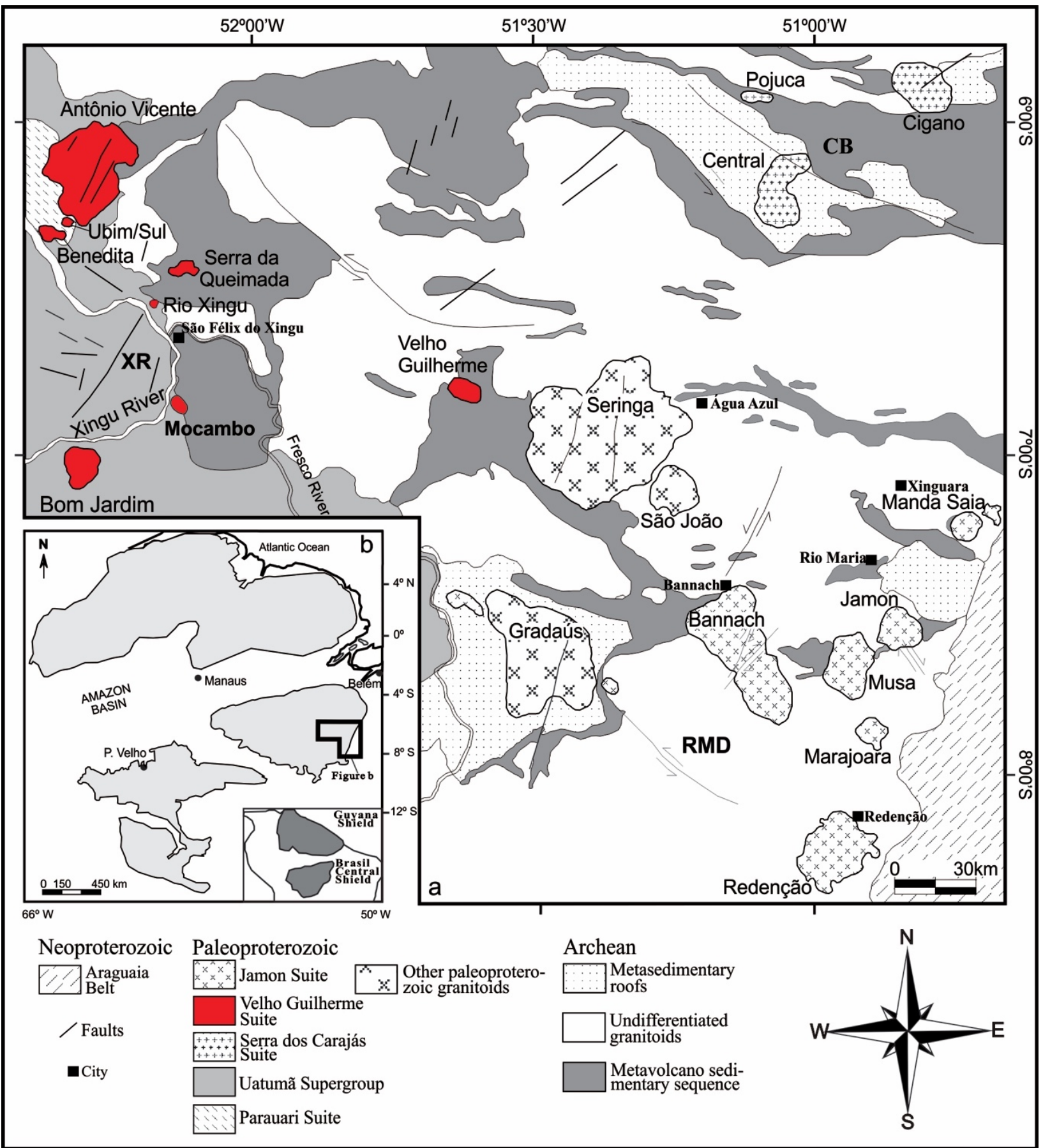

RMD: Rio Maria Domain; CB: Carajás Basin; XR: Xingu Region.

Source: modified from Dall'Agnol et al. (2005).

Figure 1. (A) Schematic map of the Amazonian Craton showing the location of the study area; (B) simplified geological map of the Carajás Province showing the distribution of anorogenic Paleoproterozoic granites. In red are the granite bodies belonging to the Velho Guilherme Intrusive Suite and the location of the Mocambo Granite, the object of this study (in bold type). 
nature and geochemical affinity with intraplate granites of subtype A2 (Whalen et al. 1987, Eby 1992). Chemical compositions of granites belonging to VGIS are shown in Table 1, with emphasis on the values referring to the Mocambo Granite.

Considering the discordant contacts of VGIS plutons with country rocks, the presence of volcanic rocks with similar ages to those of the VGIS (1.87-1.88 Ga; Teixeira et al.2002, 2005, Dall'Agnol et al. 2005, Pinho et al. 2006), the contact metamorphism (Dall'Agnol 1980), and porphyry granites, Teixeira (1999) reported a shallow level of emplacement, pressures between 1 and $5 \mathrm{kbar}$ and temperatures from 700 to $880^{\circ} \mathrm{C}$ in a low oxygen fugacity environment.

\section{MOCAMBO GRANITE}

The Mocambo Granite has been characterized in geological, petrographical, geochemical, and geochronological terms by Teixeira and Dall'Agnol (1991), Teixeira (1999), and Teixeira et al. $(2002,2005)$. It is composed of syenogranites to monzogranites, with subordinate alkali feldspar granites. According to Teixeira et al. (2005), the Mocambo Granite is a highly fractionated dome affected by late- to post-magmatic processes and contains cassiterite, wolframite, topaz, fluorite, sphalerite, wolframoixiolite, yttrofluorite, and yttrocerite. It consists of a main pluton and three smaller satellites (Fig. 2), and intrudes into mafic metasedimentary and metavolcanic rocks of the São Félix group as well as into volcanic rocks of the Sobreiro Formation (Uatumã Supergroup) (Abreu and Ramos 1974, CPRM/DNPM 1997, Juliani and Fernandes 2010).

Despite hosting notable tin concentrations similar to other plutons of the VGIS, the Mocambo Granite is not a primary economic deposit. The cassiterite is mined from placer deposits by manual extraction.

\section{PETROGRAPHIC AND COMPOSITIONAL CHARACTERISTICS}

Based on petrographic studies (Teixeira 1999), the following facies of the Mocambo pluton were identified:

Table 1. Chemical compositions of granitic rocks of the Velho Guilherme Intrusive Suite. Oxide in wt.\% and trace elements in ppm. (Chemical data from Teixeira 1999, Teixeira et al. 2005, Lamarão et al. 2012).

\begin{tabular}{|c|c|c|c|c|c|c|c|c|c|c|c|c|c|c|}
\hline \multirow{2}{*}{$\begin{array}{l}\text { Granite } \\
\text { Facies }\end{array}$} & \multicolumn{3}{|c|}{ Mocambo } & \multicolumn{5}{|c|}{ Antônio Vicente } & \multicolumn{3}{|c|}{ Velho Guilherme } & \multicolumn{3}{|c|}{ Bom Jardim } \\
\hline & PSMG & MvSG & AAFG & BASMG & BMG & BSG & ABSG & IABSG & EBSG & HSG & MSG & $\begin{array}{l}\text { BMZG - } \\
\text { BLMZG }\end{array}$ & BSG & GREISEN \\
\hline$n^{\circ}$ analyzes & 2 & 2 & 1 & 3 & 3 & 5 & 4 & 6 & 4 & 5 & 1 & 9 & 4 & 4 \\
\hline $\mathrm{SiO}_{2}$ (wt.\%) & 75.91 & 75.95 & 76.76 & 68.38 & 75.41 & 76.34 & 77.12 & 75.06 & 75.9 & 76.42 & 77.41 & 75.02 & 76.3 & 74.07 \\
\hline $\mathrm{TiO}_{2}$ & 0.04 & 0.06 & 0.04 & 0.78 & 0.18 & 0.14 & 0.09 & 0.05 & 0.05 & 0.05 & 0.03 & 0.12 & 0.03 & 0.03 \\
\hline $\mathrm{Al}_{2} \mathrm{O}_{3}$ & 12.94 & 12.62 & 12.64 & 14.02 & 12.3 & 12.27 & 12.36 & 12.84 & 12.4 & 12.37 & 12.61 & 13.09 & 13.44 & 13.87 \\
\hline $\mathrm{Fe}_{2} \mathrm{O}_{3}$ & 2.40 & 3.05 & 1.02 & 1.99 & 1.52 & 0.34 & 0.35 & 0.26 & 1.54 & 1.14 & 0.48 & 1.45 & 0.72 & 5.44 \\
\hline $\mathrm{FeO}$ & na & na & na & 2.80 & 1.29 & 1.36 & 1.09 & 0.9 & na & na & na & na & na & na \\
\hline $\mathrm{MnO}$ & 0.06 & 0.09 & 0.02 & 0.06 & 0.01 & 0.03 & 0.02 & 0.02 & 0.015 & 0.01 & na & 0.05 & 0.02 & 0.29 \\
\hline $\mathrm{MgO}$ & 0.02 & 0.01 & 0.02 & 0.81 & 0.18 & 0.12 & 0.05 & 0.02 & 0.01 & 0.03 & 0.03 & 0.10 & 0.04 & 0.02 \\
\hline $\mathrm{CaO}$ & 0.57 & 0.58 & 0.43 & 1.67 & 0.48 & 0.73 & 0.77 & 1.02 & 0.49 & 1.01 & 0.53 & 0.56 & 0.15 & 0.46 \\
\hline $\mathrm{Na}_{2} \mathrm{O}$ & 3.25 & 2.59 & 2.03 & 3.93 & 3.34 & 3.28 & 3.50 & 3.27 & 3.60 & 3.78 & 3.25 & 3.46 & 4.35 & 0.05 \\
\hline $\mathrm{K}_{2} \mathrm{O}$ & 4.03 & 4.53 & 6.38 & 4.12 & 5.13 & 4.74 & 4.76 & 4.72 & 4.63 & 4.27 & 5.66 & 4.99 & 4.35 & 3.14 \\
\hline $\mathrm{P}_{2} \mathrm{O}_{5}$ & 0.01 & 0.01 & 0.01 & 0.24 & 0.06 & 0.03 & 0.02 & 0.02 & 0.01 & $\begin{array}{c}< \\
0.01\end{array}$ & 0.03 & 0.03 & 0.01 & 0.02 \\
\hline P.F. & 0.85 & 1.14 & 0.89 & 0.88 & 0.69 & 0.81 & 0.68 & 0.84 & 0.70 & 0.50 & 0.52 & 1.04 & 0.60 & 2.52 \\
\hline Total & 100 & 100 & 100 & 99.68 & 100.59 & 100.19 & 100.81 & 99.62 & 99.32 & 99.12 & 100.57 & 99.91 & 100 & 99.91 \\
\hline $\mathrm{Rb}(\mathrm{ppm})$ & 835 & 786 & 871 & 248 & 296 & 306 & 433 & 539 & 511 & 433 & 365 & 526 & 798 & 1355 \\
\hline $\mathrm{Ba}$ & 310 & 28 & 32 & 1170 & 447 & 245 & 129 & 29 & 16 & 175 & 264 & 346 & 18 & 15 \\
\hline $\mathrm{Sr}$ & 21 & 18 & 19 & 148 & 42 & 34 & 25 & 11 & 9 & 70 & 49 & 51 & 7 & 20 \\
\hline $\mathrm{Zr}$ & 118 & 164 & 152 & 327 & 201 & 167 & 132 & 118 & 130 & 121 & 161 & 153 & 111 & 66 \\
\hline $\mathrm{Nb}$ & 126 & 76 & 120 & 17 & 21 & 25 & 42 & 51 & 38 & 41 & 52 & 38 & 55 & 54 \\
\hline Y & 15 & 170 & 79 & 112 & 25 & 57 & 83 & 148 & 107 & 122 & 237 & 51 & 35 & 39 \\
\hline Sn & 19 & 63 & 10 & 7 & 6 & 2 & 7 & 303 & 3 & 10 & 2 & 8 & 13 & 159 \\
\hline $\mathrm{F}$ & 14,500 & 7,550 & 3,400 & 897 & 1,063 & 2,580 & 3,675 & 6,567 & 2,500 & 2,680 & 1,594 & 2,340 & 1,743 & 12,120 \\
\hline W & 182 & 81 & 88 & 51 & 65 & 135 & 55 & 50 & 78 & 60 & 715 & 58 & 45 & 88 \\
\hline $\mathrm{Ta}$ & 16 & 10 & 18 & 2 & 2 & 7 & 6 & 9 & 6 & 5 & 9 & na & na & na \\
\hline $\mathrm{Hf}$ & 7 & 10 & 12 & 7 & 6 & 78 & 60 & 44 & 8 & 8 & 12 & 7 & 10 & 6 \\
\hline Th & 5 & 74 & 59 & 36 & 83 & 33 & 36 & 39 & 48 & 45 & 45 & 44 & 35 & 30 \\
\hline $\mathrm{U}$ & 18 & 17 & 20 & 14 & 17 & na & na & na & 13 & 11 & 20 & 12 & 20 & 12 \\
\hline
\end{tabular}

PSMG: porphyritic syenogranite to monzogranite; MvSG: muscovite-bearing syenogranite; AAFG: aplite-alkali feldspar-granite; BASMG: biotite amphibole syenogranite to monzogranite; BMG: biotite monzogranite; BSG: biotite syenogranite; ABSG: altered biotite syenogranite; IABSG: intensely altered biotite syenogranite; EBSG: equigranular biotite syenogranite; HSG: heterogranular syenogranite; MSG: muscovite syenogranite; BMZG: biotite monzogranite; BLMZG: biotite leucomonzogranite; na: not analyzed. 
- Porphyritic syenogranite to monzogranite (PSMG);

- Muscovite-bearing syenogranite (MvSG);

- Aplite alkali feldspar granite (AAFG) and Siderophyllitechlorite-muscovite-quartz greisen (SCMQGs) associated with these rocks.

The samples corresponding to each facies of the Mocambo Granite were plotted in the QAP diagram (Fig. 3) and their main petrographic characteristics are listed in Table 2 . The rocks vary from syenogranite to monzogranite, or less frequently to alkali feldspar granite, and a variety of MvSG belonging to quartz-enriched granitoids.
PSMG is pink to whitish-grey, hololeucocratic, mediumto coarse-grained, with a porphyritic texture and fine- to medium-grained matrix (Fig. 4A). It consists primarily of quartz, K-feldspar, and oligoclase, with biotite as the main mafic mineral (Fig. 4B). K-feldspar and quartz phenocrysts are predominantly subhedral (Fig. 4C). The accessory minerals are zircon, monazite, allanite, fluorite, and topaz, and secondary minerals include muscovite/sericite, chlorite, epidote, carbonate, and K-feldspar associated with the partial replacement of plagioclase, as well as albite and clay minerals associated with the alteration of primary K-feldspar.

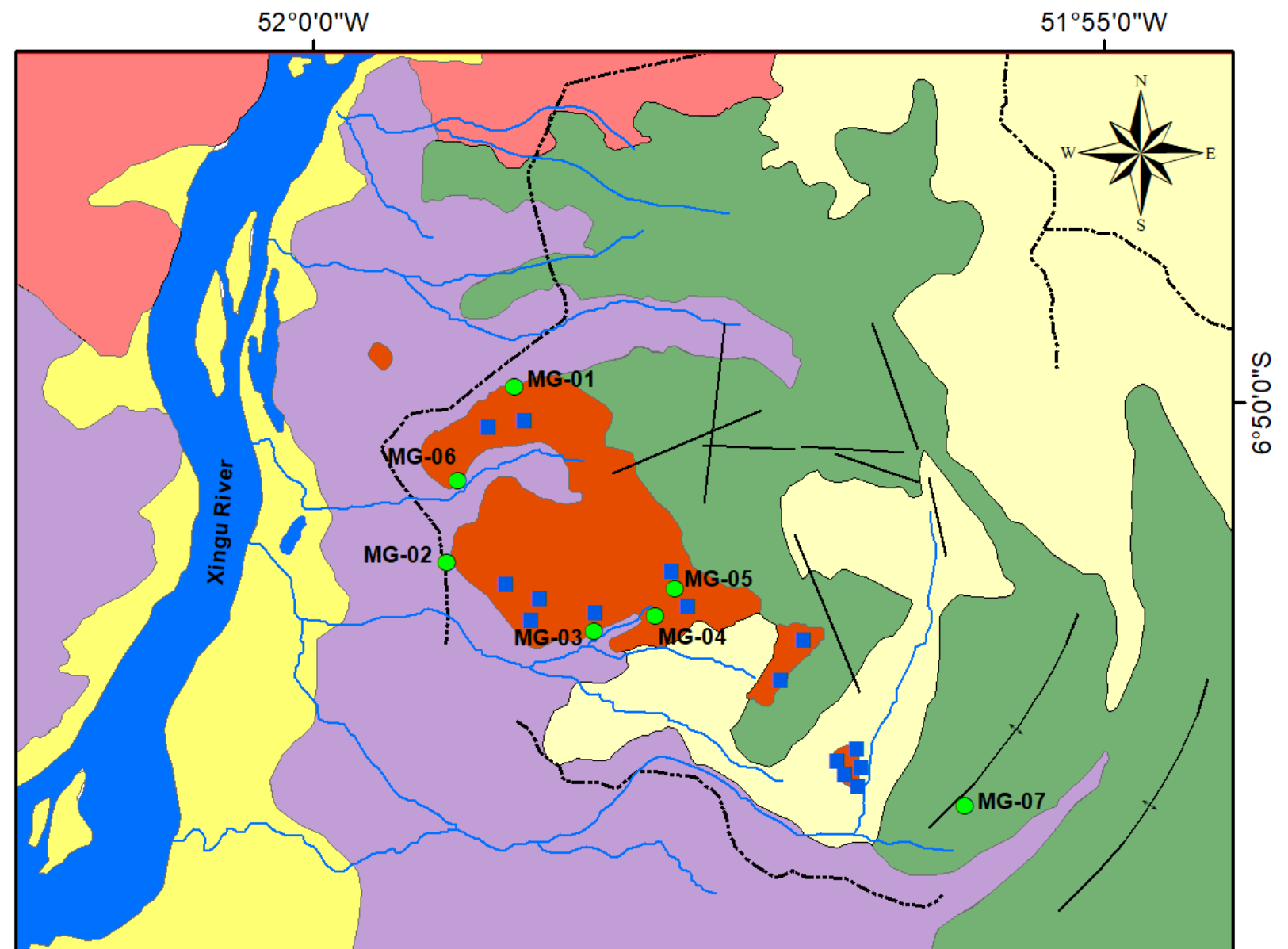

Lithostratigraphic

\section{$\square$ Alluvial sediments}

Mocambo Granite: Porphyritic syenogranite to monzogranite and syenogranite with associated muscovite-siderophillytechlorite-quartz greisen

\section{Uatumã Supergroup}

Iriri Group: Rhyolite and rhyolitic tuffs with rhyodacites, dacites, subordinate dacite and rhyodacite tuffs

Sobreiro Formation: Andesitic rocks with subordinate trachytes and trachyandesites

\section{São Felix Group}

\section{$\square$ Metasedimentary rocks \\ Mafic metavolcanic rocks}

\section{Cartographic convetions}

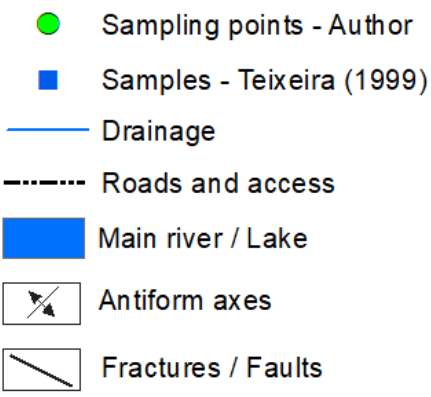

Figure 2. Geological map of the Mocambo Granite and adjacent rocks, showing new sampling points visited during field work and the samples collected by Teixeira (1999). 


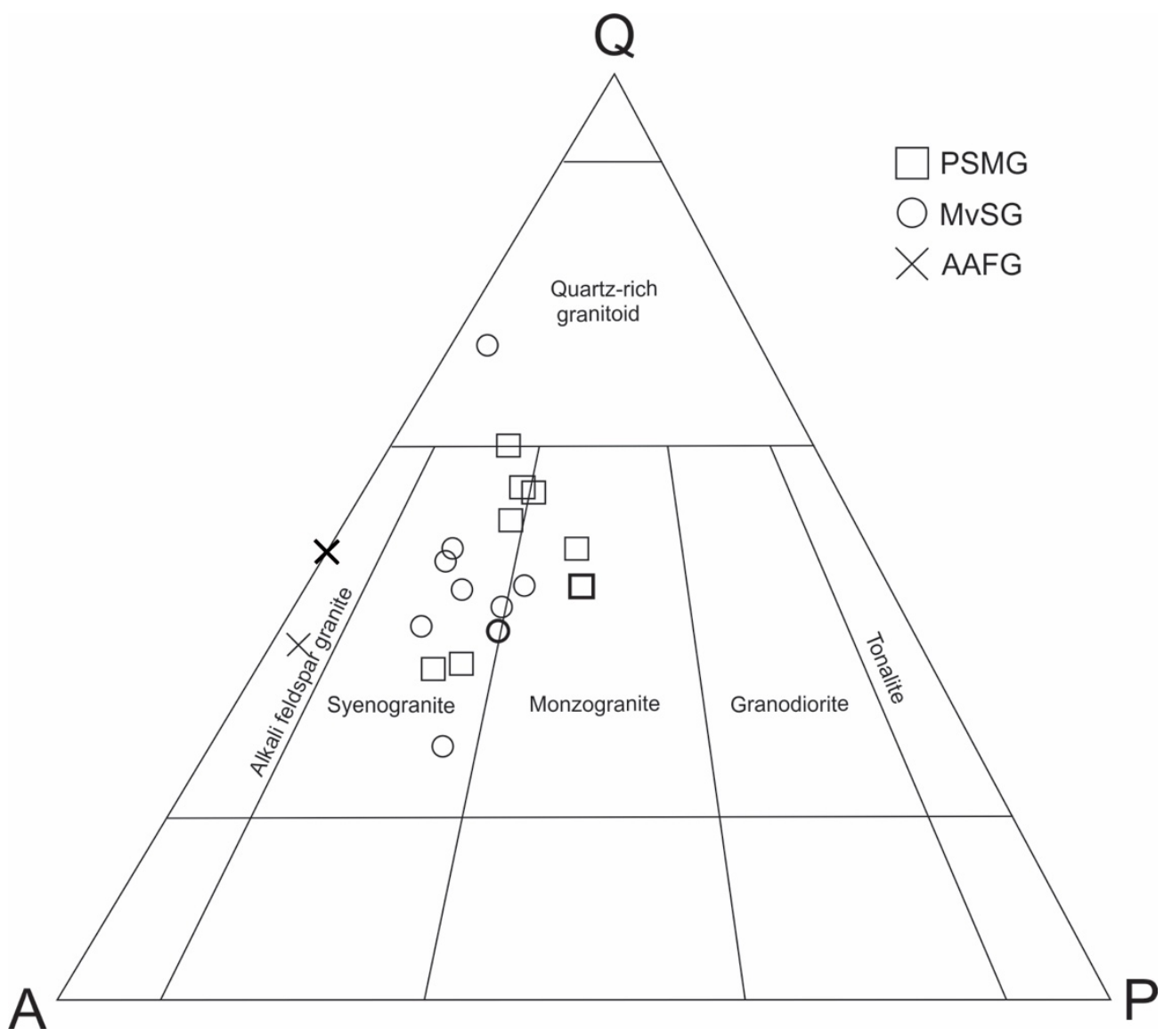

Source: modified from Teixeira et al. (2002, 2005).

Figure 3. QAP diagram (Streckeisen 1976) showing the modal composition of the Mocambo Granite samples. Samples collected during the fieldwork of the present study are shown in bold.

Table 2. Mineralogical characteristics in the main granitic facies and greisens of the Mocambo Granite.

\begin{tabular}{|c|c|c|c|c|c|}
\hline & $\begin{array}{l}\text { Essential } \\
\text { (\% modal) }\end{array}$ & $\begin{array}{l}\text { Varietal } \\
\text { (\% modal) }\end{array}$ & Accessory & Secondary & $\begin{array}{c}\text { Mineralization / } \\
\text { occurrence }\end{array}$ \\
\hline PSMG & $\begin{array}{l}\text { Quartz ( } 25 \text { to } 49) \text {, } \\
\text { plagioclase ( } 9 \text { to } \\
21), \text { K-feldspar } \\
\text { ( } 8 \text { to } 32)\end{array}$ & $\begin{array}{l}\text { Biotite } \\
(<1 \text { to } 3)\end{array}$ & $\begin{array}{l}\text { Zircon, monazite, } \\
\text { columbite-tantalite, } \\
\text { allanite, topaz }\end{array}$ & $\begin{array}{c}\text { Muscovite / } \\
\text { sericite, chlorite, } \\
\text { epidote, microcline, } \\
\text { albite, and clay } \\
\text { minerals }\end{array}$ & $\begin{array}{c}\text { Topaz } \\
\text { and fluorite / } \\
\text { disseminated }\end{array}$ \\
\hline MvSG & $\begin{array}{l}\text { Quartz (32 to } 50), \\
\text { plagioclase ( } 2 \text { to } \\
\text { 17), K-feldspar } \\
\text { (6 to } 26)\end{array}$ & $\begin{array}{l}\text { Biotite } \\
(<1 \text { to } 1)\end{array}$ & $\begin{array}{c}\text { Zircon, rutile, } \\
\text { monazite, fluorite, } \\
\text { topaz columbite- } \\
\text { tantalite, thorite, } \\
\text { allanite, sphalerite, } \\
\text { cassiterite }\end{array}$ & $\begin{array}{l}\text { Muscovite / } \\
\text { sericite, chlorite, } \\
\text { carbonate, } \\
\text { microcline, albite, } \\
\text { and clay minerals }\end{array}$ & $\begin{array}{l}\text { Cassiterite } \\
\text { and fluorite/ } \\
\text { disseminated }\end{array}$ \\
\hline AAFG & $\begin{array}{c}\text { Quartz (47) } \\
\text { K-feldspar / Albite } \\
\quad(30-40)\end{array}$ & & $\begin{array}{l}\text { Zircon, rutile, } \\
\text { thorite, columbite, } \\
\text { sphalerite, fluorite, } \\
\text { monazite, allanite }\end{array}$ & $\begin{array}{l}\text { Muscovite / } \\
\text { sericite, albite, and } \\
\text { clay minerals }\end{array}$ & Absent \\
\hline $\begin{array}{l}\text { SCMQGs and } \\
\text { greisenized rocks }\end{array}$ & $\begin{array}{c}\text { Quartz, } \\
\text { siderophyllite, } \\
\text { muscovite }\end{array}$ & & $\begin{array}{l}\text { Zircon, columbite- } \\
\text { tantalite, monazite, } \\
\text { allanite, thorite, } \\
\text { sphalerite, and } \\
\text { cassiterite }\end{array}$ & $\begin{array}{c}\text { Muscovite / } \\
\text { sericite, chlorite, } \\
\text { phengite } \\
\text { siderophyllite, } \\
\text { quartz, albite }\end{array}$ & $\begin{array}{l}\text { Cassiterite/ massive } \\
\text { and disseminated }\end{array}$ \\
\hline Quatz veins & Quartz & & & Muscovite, chlorite & $\begin{array}{c}\text { Cassiterite and } \\
\text { wolframite / } \\
\text { disseminated and } \\
\text { massive }\end{array}$ \\
\hline
\end{tabular}

MG: Mocambo Grande; PSMG: porphyrytic syenogranite to monzogranite; MvSG: muscovite-bearing syenogranite AAFG: aplite-alkali-feldspar-granite; SCMQGs: siderophyllite-chlorite-muscovite-quartz greisen bodies.

Source: modified from Teixeira (1999). 
MvSG is whitish-grey in color, medium-grained, with hypidiomorphic texture and tends to be equigranular (Fig. 4D). It is composed essentially of quartz, oligoclase, K-feldspar, and $<1 \%$ biotite (Fig. $4 \mathrm{E}$ ). The accessory phases are represented by zircon, fluorite, monazite, columbite-tantalite, thorite, sphalerite, allanite, topaz, and cassiterite. The secondary minerals are muscovite/sericite, chlorite, albite, and clay minerals are related to the alteration of potassium feldspar.

According to Teixeira (1999), AAFG is hololeucocratic, white to greenish-grey, medium-grained, and tends to be porphyritic. The primary components are quartz and K-feldspar, with zircon, thorite, columbite, sphalerite, fluorite, monazite, allanite, and rutile as accessories. The late to post-magmatic phases are represented by muscovite/sericite and albite; however, during this study, a variation of AAFG was identified consisting primarily of quartz and sodic plagioclase, with muscovite as the varietal mineral (Figs. 4F and 4G).

The greisenized rocks (GR) vary in color from light to dark greenish-grey and are fine to coarse-grained, with a hypidiomorphic heterogranular texture (Fig. $4 \mathrm{H}$ ). They are composed of quartz, muscovite/sericite, chlorite (Figs. 4I and $4 \mathrm{~J}$ ), and may also contain siderophyllite, phengite, zircon, monazite, allanite, columbite-tantalite, thorite, sphalerite, albite, fluorite, and cassiterite. Quartz veins with wolframite, cassiterite, muscovite, and chlorite crosscut the most evolved (fractionated) rocks, as well as greisen bodies (Figs. 4L and 4M).

Table 2 depicts the mineralogical characteristics and mineralization present in the facies and variations of Mocambo Granite rocks.
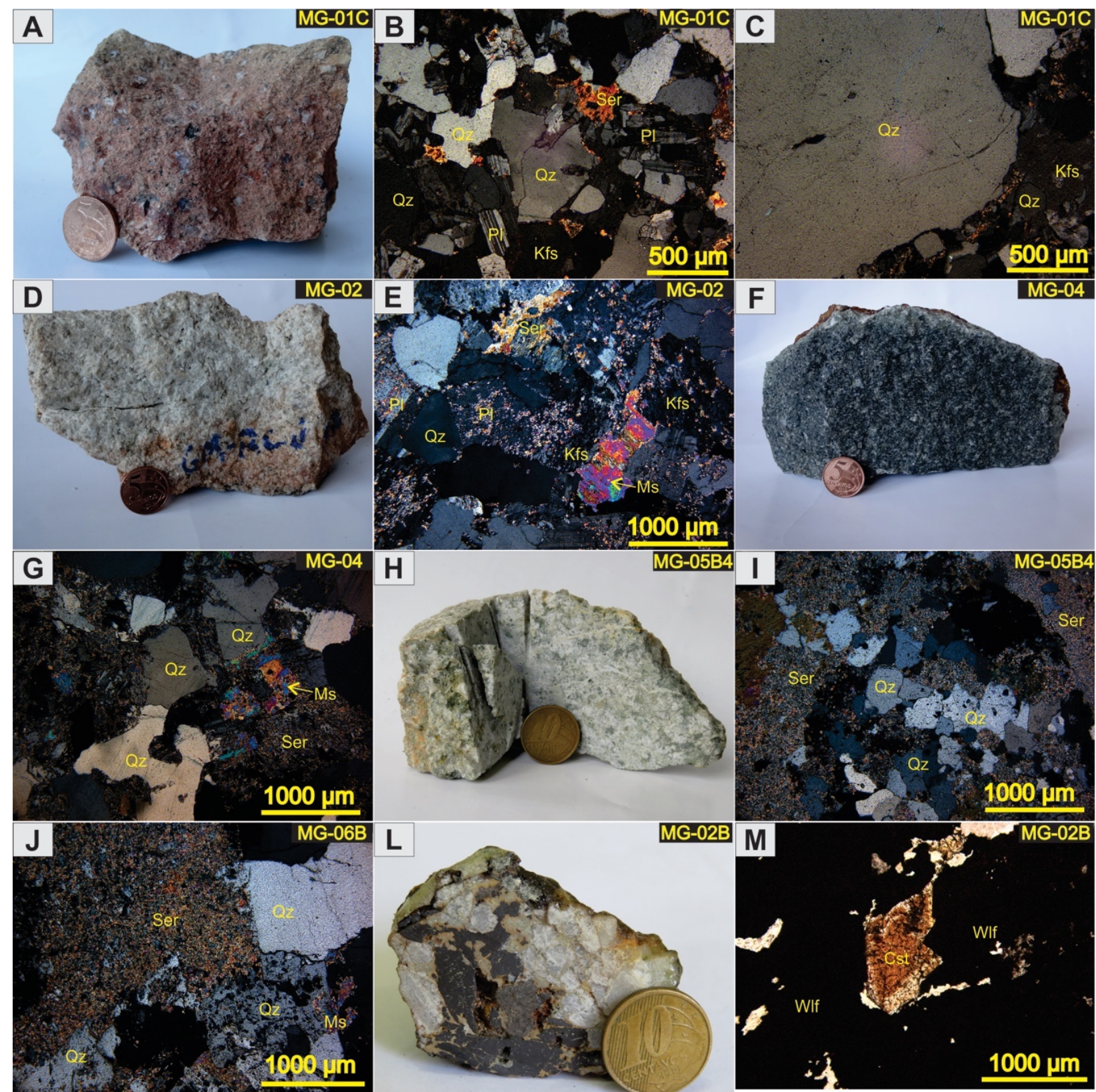

Figure 4. Textural and mineralogical aspects of the Mocambo Granite samples: (A, B and C) porphyritic syenogranite to monzogranite (PSMG) with inequigranular texture (B) and quartz phenocrysts (C); (D and E) muscovite-bearing syenogranite (MvSG) with intense muscovitization and sericitization (E); (F and G) aplite alkali feldspar granite (AAFG) (F) with intense alteration of albite crystals to sericite and muscovite (G); $(\mathrm{H}, \mathrm{I}$ and $\mathrm{J}$ ) greisenized rock $(\mathrm{H})$ showing complete feldspar alteration to sericite ( $\mathrm{I}$ and $\mathrm{J}$ ); (L) quartz vein containing wolframite and cassiterite; (M) Cassiterite included in a wolframite crystal. Parallel polarizer (M). Acronyms in accordance with Whitney and Evans (2010). 


\section{METHODOLOGY}

Eleven polished sections of the different granitic facies and greisens of the Mocambo Granite were used. The SEM-CL images were obtained using a LEO-ZEISS 1430 SEM from the Laboratório de Microanálises of the Instituto de Geociências of the Universidade Federal do Pará (UFPA), with a Gatan Mono-CL 3 system, under the following conditions: electron beam current $=90 \mu \mathrm{a}$, constant acceleration voltage $=10 \mathrm{kV}$ and working distance $=13 \mathrm{~mm}$. The polished sections were previously gold sputtering coated for 30 seconds. Quartz and cassiterite quantitative chemical analyses and cassiterite chemical mapping by wavelength dispersive spectroscopy (WDS) were performed at the Laboratório de Microanálises of the Instituto de Geociências, using a JEOL JXA-8230 electron microprobe equipped with 5 WDS spectrometers. The operating conditions are presented in Table 3. The following elements, standards, and analyzer crystals were used for quartz analyses: $\mathrm{Al}$ - orthoclase - Thallium acid phthalate (TAP), $\mathrm{Si}-\mathrm{SiO}_{2}-$ Pentaerythritol (PET), $\mathrm{Ti}-\mathrm{TiO}_{2}-$ Lithium fluoride (LIF); and for cassiterite: $\mathrm{Nb}-\mathrm{Nb}-\mathrm{TAP}, \mathrm{Ta}-\mathrm{Ta}-\mathrm{TAP}, \mathrm{Sn}$ - cassiterite - PET, $\mathrm{Si}-\mathrm{SiO}_{2}-\mathrm{PET}, \mathrm{Fe}-\mathrm{Fe}_{3} \mathrm{O}_{4}-\mathrm{LIF}, \mathrm{Mn}$ - rhodonite - LIF, Ti - $\mathrm{TiO}_{2}-\mathrm{PET}$, Mo - Mo - PET, W - W - PET. Detection limits $(\mathrm{Al}=5 \mathrm{ppm}, \mathrm{Ti}=8 \mathrm{ppm})$ were calculated from 58 background measurements with $95 \%$ confidence according to Müller et al. (2002, 2003). Ti, Al, K, and Fe were analyzed; however, $\mathrm{K}$ and $\mathrm{Fe}$ levels were very low and therefore disregarded. For the electron microprobe analyses, the polished sections were carbon-coated.

\section{RESULTS}

\section{Quartz types}

Based on the morphological and textural aspects analyzed by $\mathrm{CL}$, five types of quartz are identified in the Mocambo Granite (MG) rocks and associated greisens:

- Qz1: the primary magmatic quartz in all types of granite facies; less common in greisenized rocks. It forms as luminescent anhedral to subhedral crystals (light grey in SEM-CL) with different degrees of fracturing, as well as fine- to medium-grained crystals dispersed in the matrix. Exhibits concentric growth zoning and resorbed nuclei are common (Figs. 5A, 5B, 5C and 5D);
- Qz2: hydrothermal quartz with low luminescence (dark grey); observed in all the facies; generally occurs as discontinuous irregular spots or micro fractures and veins that crosscut Qz1, suggesting intense replacement (Figs. 5B, $5 \mathrm{C}$ and $5 \mathrm{D})$;

- Qz3: non-luminescent hydrothermal quartz. Occurs in practically all the facies filling the fractures that crosscut Qz1 and Qz2 (Figs. 5C and 5D);

- Qz4: present in the most evolved and intensely altered rocks, greisen bodies and veins or interstitial cavities, generally associated with cassiterite crystals. It forms medium-grained, euhedral to subhedral crystals, with little fracturing, well-defined, variable thickness, light to dark zoning (Figs. 5E, 5F, 5G and 5H);

- Qz5: crosscuts Qz4 and forms irregular spots (Figs. 5F, $5 \mathrm{G}$ and $5 \mathrm{H}$ ), generally associated with wolframite or wolframite + cassiterite in quartz veins. The anhedral crystals are medium to coarse-grained with little fracturing and non-luminescent, reflecting the absence or low content of CL activators (Fig. 5I).

\section{Quartz chemistry}

A total of 146 EMP analyses were performed on quartz crystals from the PSMG, AAFG, GR and mineralized veins of the Mocambo Granite (Tab. 4).

Quartz crystals from the less evolved PSMG, AAFG and GR showed higher average $\mathrm{Ti}$ and lower Al concentrations when compared to those from greisenized rocks mineralized in cassiterite (GRSn). On the other hand, quartz crystals from veins mineralized in wolframite or wolframite + cassiterite (VWSn) exhibited the lowest Ti and Al levels (Fig. 6).

Qz1 exhibits high $\mathrm{Ti}(\leq 103 \mathrm{ppm})$ and varied $\mathrm{Al}$ content ( $\leq 604$ ppm; Tab. 4; Fig. 7), with concentrations of $\mathrm{Al} \leq 2,065$ ppm and $\mathrm{Ti} \leq 20$ ppm in Qz2 (Tab. 4; Fig. 7). There is a clear relationship between luminescent areas and higher amounts of Ti (Figs. 8A, 8B and 8C). Qz3 is extremely depleted in Ti and $\mathrm{Al}$, which are almost always below the detection limit (Figs. 7 and 8; Tab. 4). The Qz4, present in the GRSn, shows high values of $\mathrm{Al}(\leq 3,733 \mathrm{ppm})$ and low Ti contents (Figs. 7 and 8; Tab. 4), though in the zones with low luminescence both elements are impoverished, being similar in this respect to Qz3 and Qz5 (Fig. 8D). Qz5 is poor in $\mathrm{Ti}$ and $\mathrm{Al}$, and may present

Table 3. Operating conditions of the electron microprobe.

\begin{tabular}{lccc}
\hline & Quartz QNT & Cassiterite QNT & Cassiterite MAP \\
\hline Voltage $(\mathrm{kV})$ & 20 & 15 & 15 \\
Beam current $(\mathrm{nA})$ & 80 & 20 & 20 \\
Beam diameter $(\mu \mathrm{m})$ & 1 & 5 & 1 \\
Matrix correction method & Phi-Rho-Z (Armstrong) & $\mathrm{ZAF}$ & - \\
Peak counting time $(\mathrm{s})$ & $\mathrm{Si}: 10 / \mathrm{Al}: 800 / \mathrm{Ti}: 800$ & $\mathrm{Sn}: 10 / \mathrm{Si}, \mathrm{Fe}, \mathrm{Mn}, \mathrm{Ti}, \mathrm{Mo}, \mathrm{W}: 60 / \mathrm{Nb}: 80$ & - \\
Background counting time $(\mathrm{s})$ & $\mathrm{Si}: 5 / \mathrm{Al}: 400 / \mathrm{Ti}: 400$ & $\mathrm{Sn}: 5 / \mathrm{Si}, \mathrm{Fe}, \mathrm{Mn}, \mathrm{Ti}, \mathrm{Mo}, \mathrm{W}: 30 / \mathrm{Nb}: 40$ & - \\
Dwell time $(\mathrm{msec})$ & - & - & 25 \\
Pixels by area $(\mathrm{px})$ & - & - & $1,550 \times 1,250$ \\
Pixel size $(\mu \mathrm{m})$ & - & - & $0.86 \times 0.86$ \\
\hline
\end{tabular}

QNT: quantitative analysis; MAP: mapping. 
a slight enrichment in the latter, but not exceeding $130 \mathrm{ppm}$

(Figs. 7, 8E and 8F).

\section{Textural and compositional variation of cassiterite}

Cassiterite is a common phase in the GR and quartz veins. It forms fine to coarse-grained anhedral to subhedral crystals and is associated with chlorite, muscovite, and phengite (Fig. 9) in GR. In quartz veins, it may occur as inclusions in wolframite. Its coloring varies from light to dark or reddish brown, often with characteristic high order interference colors. Well-shaped crystals with well-defined zoning are common in GR. By contrast, cassiterite crystals in veins associated with wolframite are frequently more fragmented, without zoning.

In addition, $\mathrm{Sn}, \mathrm{Fe}, \mathrm{Ti}, \mathrm{Nb}$, and $\mathrm{W}$ concentrations were analyzed in cassiterite, with no significant variation in mean values. Titanium showed slight enrichment in samples without wolframite. Tungsten and iron enrichment was slightly higher in cassiterite associated with quartz veins mineralized in wolframite, and $\mathrm{Nb}$ concentrations showed no significant variation. The mean $\mathrm{Sn}$ concentration was around $98.5 \mathrm{wt} . \%$, with the highest values observed in sample GM-SN-02 (average of 99.1 wt.\%). The Mn, Mo, and Ta levels were close to zero (Tab. 5).

A comparison of the cassiterite crystal regions analyzed by EMP and observed under parallel polarizer demonstrates that the light brown zones exhibit higher $\mathrm{Sn}$ and lower $\mathrm{Ti}$, $\mathrm{W}$, and $\mathrm{Nb}$ concentrations than the dark brown and orange zones. The dark brown zones and fractures are $\mathrm{W}$-enriched (Fig. 10). Compositional maps revealed $\mathrm{Fe}$ and Ti-enriched growth zones (Fig. 11).

\section{DISCUSSION}

\section{Morphological-textural variation of quartz}

The CL images made it possible to identify 5 different types of quartz in the MG as well as the chronological order of the magmatic-hydrothermal stages involved in its evolution.

At the onset of hydrothermal processes, deuteric fluids percolated through the rocks of the Mocambo Granite, interacting with the magmatic, bright luminescent Qz1, and forming dark grey Qz2, primarily along the edges of the magmatic crystals (Fig. 12, stage 1), altering their chemical composition. During this process, non-luminescent Qz3 crystallized, filling fractures in Qz1 and, occasionally, in Qz2 (Fig. 12, stage 2). These alteration, dissolution, and recrystallization processes were also described in previous studies ( $c f$. Rusk and Reed 2002, Larsen et al. 2009, Lamarão et al. 2013, 2014, Sotero et al.2015). Qz4 represents a later alteration and crystallization stage than the previous quartz types (Fig. 12, stage 3 ) and is commonly associated with cassiterite mineralization in hydrothermally altered rock and the greisen bodies. Qz4 crystals are predominantly euhedral to subhedral, with the well-defined luminescent and non-luminescent zoning typical of hydrothermal quartz ( $c f$. Rusk and Reed 2002, Rusk et al. 2008, Lamarão et al. 2013, 2014, Sotero et al. 2015, Breiter et al. 2017). Qz5 represents the last hydrothermal event, formed by the continuous percolation of fluids that crosscut and consumed Qz4 (Fig. 12, stage 4). It is homogeneous, non-luminescent, present in veins mineralized in wolframite, which may contain a small amount of cassiterite. Additionally, the constant presence of cassiterite inclusions in the wolframite suggest that wolframite is younger than cassiterite and that Qz5, the wolframite host, is the youngest quartz type.
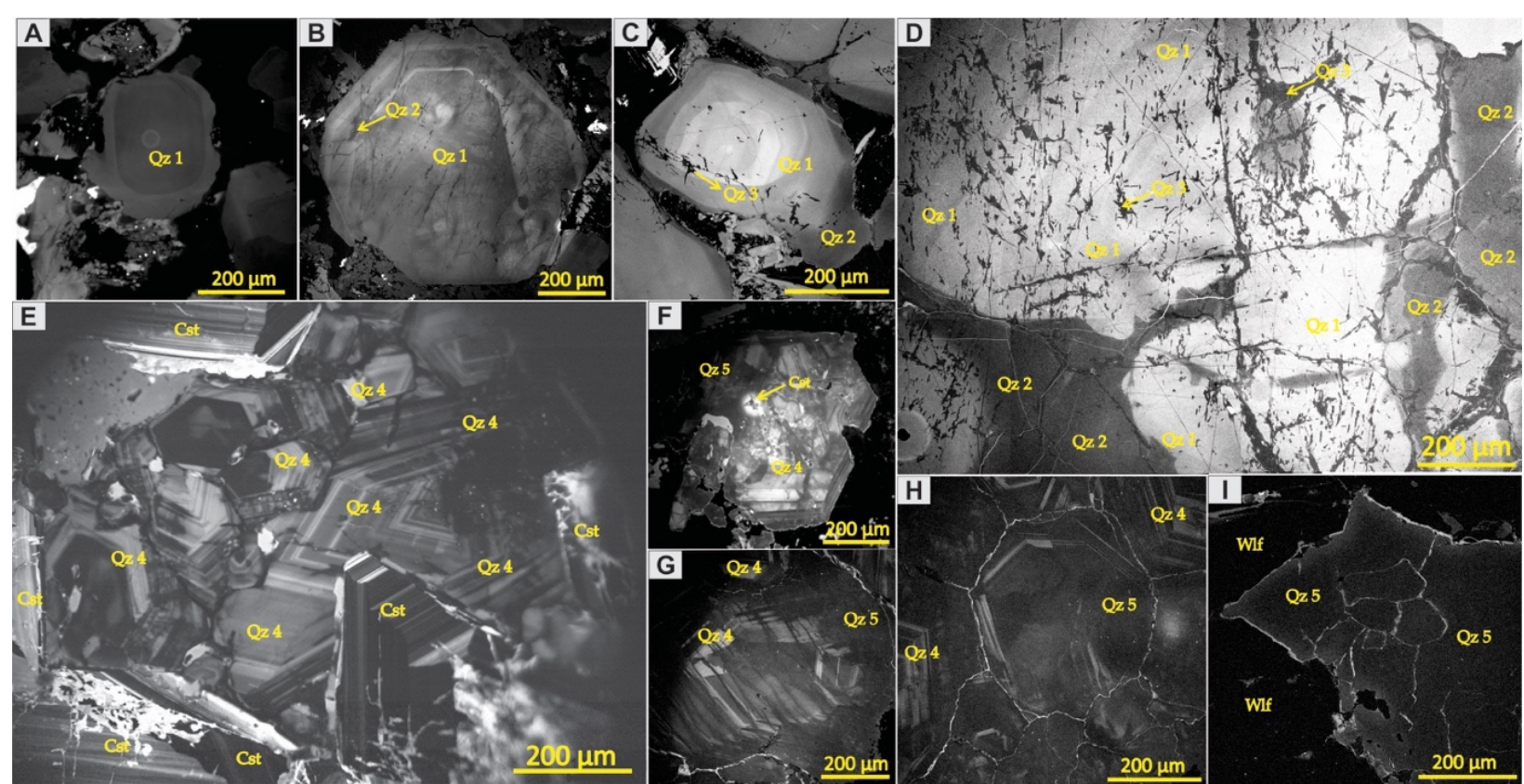

Figure 5. Scanning electron microscopy cathodoluminescence images showing the quartz types and their morphological and textural evolution in the Mocambo Granite: (A) magmatic quartz (Qz1) with weak zoning; (B) zoned Qz1 with small spots of Qz2; (C) Zoned and luminescent Qz1 resorbed by Qz2 and crosscut by Qz3; (D) luminescent Qz1 crosscut by dark grey Qz2; black Qz3 crosscutting Qz1 and Qz2; (E) hydrothermal euhedral Qz4, with well-defined dark grey zoning associated with cassiterite (Cst); (F) cassiterite associated with Qz4 and Qz5; (G and H) Qz5 crosscutting Qz4 (G) or occurring on it as spots; (I) Qz5 homogeneous with low luminescence, generally associated with wolframite (Wlf) or wolframite + cassiterite. 
Braz. J. Geol. (2020), 50(4): e20190096

Table 4. Ti and Al concentrations (ppm) in quartz crystals from PSMG (GM-01-C), AAFG (GM-04), GR (GM-05B4), GRSn (GM-SN-03) and VWSn (GM-SN-06).

\begin{tabular}{|c|c|c|c|c|c|c|c|c|c|c|c|}
\hline Sample & $\begin{array}{c}\text { Al } \\
\text { ppm }\end{array}$ & $\begin{array}{c}\text { Ti } \\
\text { ppm }\end{array}$ & $\begin{array}{c}\text { Qz } \\
\text { Type }\end{array}$ & Sample & $\begin{array}{c}\text { Al } \\
\text { ppm }\end{array}$ & $\begin{array}{c}\text { Ti } \\
\text { ppm }\end{array}$ & $\begin{array}{c}\text { Qz } \\
\text { Type }\end{array}$ & Sample & $\begin{array}{c}\text { Al } \\
\text { ppm }\end{array}$ & $\begin{array}{c}\mathbf{T i} \\
\mathbf{p p m}\end{array}$ & $\begin{array}{c}\text { Qz } \\
\text { Type }\end{array}$ \\
\hline GM-01-C_1-1 & 77 & 61 & Qz1 & GM-05-B4_1-5 & 29 & 28 & Qz1 & GM-SN-03_4-3 & 29 & {$[1]$} & Qz4 \\
\hline GM-01-C_1-2 & 77 & 61 & Qz1 & GM-05-B4_1-6 & 165 & 62 & Qz1 & GM-SN-03_4-4 & 16 & {$[0]$} & Qz3 \\
\hline GM-01-C_1-3 & 20 & 10 & Qz2 & GM-05-B4_1-7 & 168 & 40 & Qz1 & GM-SN-03_4-5 & 897 & {$[7]$} & Qz4 \\
\hline GM-01-C_1-4 & 37 & 37 & Qz1 & GM-05-B4_1-8 & 47 & 11 & Qz2 & GM-SN-03_4-6 & 103 & {$[7]$} & Qz4 \\
\hline GM-01-C_1-5 & 149 & 51 & Qz1 & GM-05-B4_1-9 & {$[0]$} & 40 & Qz1 & GM-SN-03_4-7 & 1104 & {$[4]$} & Qz4 \\
\hline GM-01-C_1-6 & 30 & 51 & Qz1 & GM-05-B4_1-10 & 86 & 19 & Qz1 & GM-SN-03_4-8 & 2547 & 10 & Qz4 \\
\hline GM-01-C_2-1 & 14 & 86 & Qz1 & GM-05-B4_1-11 & 67 & 22 & Qz1 & GM-SN-03_4-9 & 275 & {$[0]$} & Qz4 \\
\hline GM-01-C_2-2 & 46 & 104 & Qz1 & GM-05-B4_1-12 & {$[0]$} & 18 & Qz1 & GM-SN-03_4-10 & {$[0]$} & {$[0]$} & Qz3 \\
\hline GM-01-C_2-3 & 61 & 16 & Qz2 & GM-05-B4_1-13 & 14 & 16 & Qz2 & GM-SN-03_4-11 & {$[0]$} & {$[0]$} & Qz3 \\
\hline GM-01-C_2-4 & 26 & 48 & Qz1 & GM-05-B4_1-14 & 31 & 33 & Qz1 & GM-SN-03_4-12 & {$[0]$} & {$[0]$} & Qz3 \\
\hline GM-01-C_2-5 & 24 & 10 & Qz2 & GM-05-B4_1-15 & {$[0]$} & {$[0]$} & Qz2 & GM-SN-03_4-13 & 1161 & {$[6]$} & Qz4 \\
\hline GM-01-C_2-6 & 11 & 11 & Qz2 & GM-05-B4_1-16 & {$[0]$} & {$[7]$} & Qz2 & GM-SN-03_4-14 & 514 & {$[0]$} & Qz4 \\
\hline GM-01-C_2-7 & 118 & 100 & Qz1 & GM-05-B4_1-17 & {$[0]$} & {$[4]$} & Qz2 & GM-SN-03_4-15 & 20 & {$[0]$} & Qz4 \\
\hline GM-01-C_3-1 & 126 & 13 & Qz2 & GM-05-B4_1-18 & 31 & {$[0]$} & Qz2 & GM-SN-03_5-1 & 2745 & {$[0]$} & Qz4 \\
\hline GM-01-C_3-2 & 41 & 50 & Qz1 & GM-05-B4_1-19 & {$[0]$} & {$[0]$} & Qz3 & GM-SN-03_5-2 & 1726 & 17 & Qz4 \\
\hline GM-01-C_3-3 & 12 & 103 & Qz1 & GM-05-B4_1-20 & 47 & 33 & Qz1 & GM-SN-03_5-3 & {$[0]$} & {$[0]$} & Qz3 \\
\hline GM-01-C_3-4 & 89 & 12 & Qz2 & GM-05-B4_1-21 & 29 & 12 & Qz1 & GM-SN-03_5-4 & {$[0]$} & {$[0]$} & Qz3 \\
\hline GM-01-C_3-5 & 23 & 56 & Qz1 & GM-05-B4_1-22 & 8 & 26 & Qz1 & GM-SN-03_5-5 & {$[0]$} & {$[0]$} & Qz3 \\
\hline GM-01-C_3-6 & 28 & 55 & Qz1 & GM-05-B4_1-23 & 165 & 46 & Qz1 & GM-SN-03_5-6 & 1329 & {$[0]$} & Qz4 \\
\hline GM-04_1-1 & 166 & {$[7]$} & Qz2 & GM-05-B4_1-24 & 27 & 42 & Qz1 & GM-SN-03_5-7 & {$[0]$} & {$[0]$} & Qz3 \\
\hline GM-04_1-2 & 491 & 16 & Qz1 & GM-05-B4_1-25 & 47 & 56 & Qz1 & GM-SN-03_5-8 & {$[0]$} & {$[3]$} & Qz3 \\
\hline GM-04_1-3 & 533 & 13 & Qz2 & GM-SN-03_1-1 & {$[0]$} & {$[5]$} & Qz3 & GM-SN-03_5-9 & 998 & {$[4]$} & Qz4 \\
\hline GM-04_1-4 & 2038 & 16 & Qz2 & GM-SN-03_1-2 & 197 & {$[1]$} & Qz4 & GM-SN-03_5-10 & 27 & 10 & Qz4 \\
\hline GM-04_1-5 & 218 & 19 & Qz2 & GM-SN-03_1-3 & {$[0]$} & {$[0]$} & Qz3 & GM-SN-03_5-11 & 2053 & 20 & Qz4 \\
\hline GM-04_2-1 & 51 & {$[5]$} & Qz2 & GM-SN-03_1-4 & 721 & {$[0]$} & Qz4 & GM-SN-03_5-12 & {$[0]$} & {$[0]$} & Qz3 \\
\hline GM-04_2-2 & 32 & 17 & Qz1 & GM-SN-03_1-5 & {$[0]$} & {$[0]$} & Qz3 & GM-SN-03_5-13 & 1354 & {$[0]$} & Qz4 \\
\hline GM-04_2-3 & 234 & {$[0]$} & Qz2 & GM-SN-03_1-6 & {$[0]$} & {$[0]$} & Qz3 & GM-SN-03_5-14 & {$[0]$} & {$[0]$} & Qz3 \\
\hline GM-04_2-4 & 102 & {$[5]$} & Qz1 & GM-SN-03_1-7 & 683 & {$[4]$} & Qz4 & GM-SN-03_5-15 & 1667 & {$[0]$} & Qz4 \\
\hline GM-04_2-5 & 95 & {$[7]$} & Qz2 & GM-SN-03_1-8 & 826 & {$[0]$} & Qz4 & GM-SN-03_5-16 & {$[0]$} & {$[0]$} & Qz3 \\
\hline GM-04_2-6 & 74 & {$[7]$} & Qz2 & GM-SN-03_2-1 & {$[0]$} & {$[0]$} & Qz3 & GM-SN-03_5-17 & 73 & {$[0]$} & Qz4 \\
\hline GM-04_3-1 & 35 & 16 & Qz1 & GM-SN-03_2-2 & 3090 & {$[0]$} & Qz4 & GM-SN-03_5-18 & 2235 & {$[0]$} & Qz4 \\
\hline GM-04_3-2 & {$[0]$} & {$[0]$} & Qz3 & GM-SN-03_2-3 & {$[0]$} & {$[0]$} & Qz3 & GM-SN-06_1-1 & 129 & {$[0]$} & Qz5 \\
\hline GM-04_3-3 & {$[0]$} & 15 & Qz1 & GM-SN-03_2-4 & 178 & {$[4]$} & Qz4 & GM-SN-06_1-2 & 24 & {$[0]$} & Qz5 \\
\hline GM-04_3-4 & 492 & 20 & Qz2 & GM-SN-03_2-5 & 452 & {$[5]$} & Qz4 & GM-SN-06_1-3 & {$[4]$} & {$[2]$} & Qz5 \\
\hline GM-04_3-5 & {$[0]$} & {$[0]$} & Qz3 & GM-SN-03_2-6 & 112 & {$[0]$} & Qz4 & GM-SN-06_1-4 & {$[0]$} & {$[7]$} & Qz5 \\
\hline GM-04_4-1 & 69 & 19 & Qz2 & GM-SN-03_2-7 & 16 & {$[0]$} & Qz3 & GM-SN-06_1-5 & 47 & {$[0]$} & Qz5 \\
\hline GM-04_4-2 & 24 & 50 & Qz1 & GM-SN-03_2-8 & {$[0]$} & {$[0]$} & Qz3 & GM-SN-06_1-6 & {$[0]$} & {$[0]$} & Qz5 \\
\hline GM-04_4-3 & 34 & 49 & Qz1 & GM-SN-03_3-1 & {$[0]$} & {$[0]$} & Qz3 & GM-SN-06_1-7 & 66 & {$[0]$} & Qz5 \\
\hline GM-04_4-4 & 53 & 87 & Qz1 & GM-SN-03_3-2 & 1304 & {$[0]$} & Qz4 & GM-SN-06_1-8 & {$[0]$} & {$[0]$} & Qz5 \\
\hline GM-04_4-5 & 38 & 38 & Qz1 & GM-SN-03_3-3 & 14 & 10 & Qz4 & GM-SN-06_2-1 & {$[0]$} & {$[0]$} & Qz5 \\
\hline GM-04_4-6 & 76 & 9 & Qz2 & GM-SN-03_3-4 & 743 & {$[0]$} & Qz4 & GM-SN-06_2-2 & {$[0]$} & {$[2]$} & Qz5 \\
\hline GM-04_4-7 & {$[0]$} & 46 & Qz1 & GM-SN-03_3-5 & 279 & 8 & Qz4 & GM-SN-06_2-3 & {$[0]$} & {$[0]$} & Qz5 \\
\hline GM-04_4-8 & 46 & {$[7]$} & Qz2 & GM-SN-03_3-6 & {$[0]$} & {$[0]$} & Qz3 & GM-SN-06_2-4 & {$[0]$} & {$[0]$} & Qz5 \\
\hline GM-04_5-1 & 604 & 48 & Qz1 & GM-SN-03_3-7 & 305 & {$[0]$} & Qz4 & GM-SN-06_2-5 & {$[0]$} & {$[0]$} & Qz5 \\
\hline GM-04_5-2 & 2065 & 16 & Qz2 & GM-SN-03_3-8 & {$[0]$} & {$[5]$} & Qz3 & GM-SN-06_2-6 & {$[0]$} & {$[0]$} & Qz5 \\
\hline GM-05-B4_1-1 & 147 & 14 & Qz1 & GM-SN-03_3-9 & 1335 & {$[0]$} & Qz4 & GM-SN-06_2-7 & {$[0]$} & {$[0]$} & Qz5 \\
\hline GM-05-B4_1-2 & 147 & {$[2]$} & Qz2 & GM-SN-03_3-10 & 2314 & {$[0]$} & Qz4 & GM-SN-06_2-8 & {$[0]$} & {$[0]$} & Qz5 \\
\hline GM-05-B4_1-3 & {$[0]$} & {$[6]$} & Qz2 & GM-SN-03_4-1 & 305 & {$[2]$} & Qz4 & GM-SN-06_2-9 & 77 & {$[5]$} & Qz5 \\
\hline GM-05-B4_1-4 & {$[0]$} & {$[0]$} & Qz3 & GM-SN-03_4-2 & 3733 & {$[2]$} & Qz4 & & & & \\
\hline
\end{tabular}

PSMG: porphyritic syenogranite to monzogranite; AAFG: aplite alkali feldspar granite; GR: greisenized rock; GRSn: cassiterite-bearing greisenized rock; VWSn: cassiterite-wolframite-bearing quartz vein. Values below the detection limit in square brackets. 


\section{Variation in $\mathrm{Ti}$ and $\mathrm{Al}$ concentrations}

The different $\mathrm{Ti}$ and $\mathrm{Al}$ concentrations in the quartz types reflects the petrogenetic and hydrothermal processes involved in their formation. Several studies (Rusk et al. 2006, 2008, Larsen et al. 2009, Breiter et al. 2017) have shown that the intensity of quartz luminescence is directly related to its Ti concentration and crystallization temperature. Quartz formed at high temperatures tends to be Ti-enriched and displays stronger luminescence, whereas low-temperature quartz tends to be Ti-depleted and less luminescent. The highest Ti concentrations (104 ppm) in the Mocambo Granite samples were found in Qz1 (magmatic) from PSMG, formed at higher temperatures. Applying the titaniQ geothermometer (Wark and Watson 2006) and considering Ti activity $=0.8$, the crystallization temperature of Qz1 is close to $780^{\circ} \mathrm{C}$. The quartz $\mathrm{Al}$ content of PSMG varied from 11 to $149 \mathrm{ppm}$ and range 0 to $600 \mathrm{ppm}$ for AAFG, with two analyses providing values $>2,000 \mathrm{ppm}$ (Tab. 4). In greisen mineralized in cassiterite, quartz crystals show significant $\mathrm{Al}$ enrichment, with some values $>3,000 \mathrm{ppm}$, while Ti was below the detection limit; however, some samples showed Ti contents up to $20 \mathrm{ppm}$, which can be interpreted as remnants of Qz1 (Tab. 4). The lowest $\mathrm{Al}$ and $\mathrm{Ti}$ concentrations were recorded in quartz veins containing wolframite (Tab. 4).

Breiter et al. (2013) studied magmatic quartz crystals from Variscan granites with different geochemical signatures and found that quartz from the highly fractionated and mineralized $\mathrm{A}$ - and S-type granites were $\mathrm{Al}$-rich and Ti-poor in relation to quartz from other granite types. Concentrations of $\mathrm{Al}$ in quartz increased as a function of water and fluorine levels (Breiter $\mathrm{et}$ al. 2013) and were also governed by the aluminum saturation index of the magma. As such, $\mathrm{Al}$ remains constant during the crystallization of metaluminous magma and increases under peraluminous conditions (Jacamon and Larsen 2009).

The $\mathrm{Al}$ and Ti values in zoned quartz and quartz mineralized in cassiterite from the Mocambo Granite are consistent with those described by Rusk et al. (2008) in low-temperature
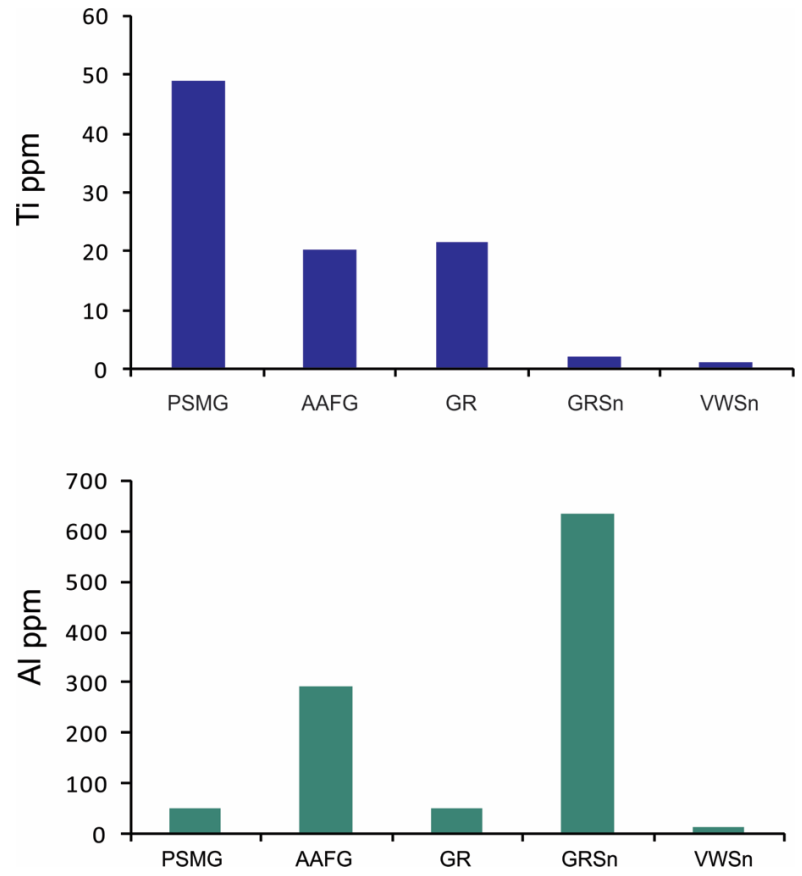

PSMG: Porphyritic syenogranite to monzogranite; AAFG: Aplite alkali feldspar granite; GR: Greisenized rock; GRSn: Greisenized rock mineralized in cassiterite; VWSn: Veins mineralized in wolframite + cassiterite.

Figure 6. Histogram showing the compositional variation of $\mathrm{Ti}$ and $\mathrm{Al}$ in quartz crystals from Mocambo Granite rocks.

Table 5. Mean values for cassiterite analyses (per sample). Oxides in wt $\%$ and elements in atoms per formula unit (apfu), calculated based on 2 oxygen atoms per formula unit. The samples in which wolframite is associated with cassiterite are shown in bold.

\begin{tabular}{|c|c|c|c|c|c|c|c|}
\hline & MG-2-A1 & MG-2-B1 & MG-2-B2 & MG-SN-6 & MG-SN-2 & MG-SN-3 & MG-SN-5 \\
\hline $\mathrm{SiO}_{2}$ & 0,01 & 0,01 & 0,02 & 0,01 & 0,01 & 0,01 & 0,01 \\
\hline $\mathrm{SnO}_{2}$ & 98,45 & 98,69 & 99,12 & 98,19 & 99,19 & 98,49 & 98,69 \\
\hline $\mathrm{TiO}_{2}$ & 0,03 & 0,07 & 0,01 & 0,01 & 0,08 & 0,51 & 0,97 \\
\hline $\mathrm{FeO}^{*}$ & 0,37 & 0,60 & 0,46 & 0,69 & 0,37 & 0,29 & 0,31 \\
\hline $\mathrm{Nb}_{2} \mathrm{O}_{5}$ & 0,10 & 0,12 & 0,09 & 0,10 & n.d & 0,27 & n.d \\
\hline $\mathrm{WO}_{3}$ & 0,27 & 0,42 & 0,09 & 0,26 & 0,02 & 0,08 & 0,07 \\
\hline $\mathrm{MnO}$ & 0,01 & 0,01 & 0,01 & 0,01 & $<\mathrm{DL}$ & $<\mathrm{DL}$ & 0,01 \\
\hline $\mathrm{MoO}_{3}$ & $<\mathrm{DL}$ & $<\mathrm{DL}$ & $<\mathrm{DL}$ & $<\mathrm{DL}$ & $<\mathrm{DL}$ & $<\mathrm{DL}$ & $<\mathrm{DL}$ \\
\hline $\mathrm{Ta}_{2} \mathrm{O}_{5}$ & $<\mathrm{DL}$ & $<\mathrm{DL}$ & $<\mathrm{DL}$ & $<\mathrm{DL}$ & $<\mathrm{DL}$ & $<\mathrm{DL}$ & $<\mathrm{DL}$ \\
\hline Total & 99,24 & 99,92 & 99,80 & 99,28 & 99,67 & 99,65 & 100,06 \\
\hline $\mathrm{Si}$ & - & - & - & - & - & - & - \\
\hline Sn & 0,991 & 0,986 & 0,992 & 0,988 & 0,994 & 0,983 & 0,978 \\
\hline $\mathrm{Ti}$ & 0,001 & 0,001 & - & - & 0,002 & 0,010 & 0,018 \\
\hline $\mathrm{Fe}^{*}$ & 0,008 & 0,012 & 0,010 & 0,015 & 0,008 & 0,006 & 0,006 \\
\hline $\mathrm{Nb}$ & 0,001 & 0,001 & 0,001 & 0,001 & - & 0,003 & - \\
\hline W & 0,002 & 0,003 & 0,001 & 0,002 & - & - & - \\
\hline $\mathrm{Mn}$ & - & - & - & - & - & - & - \\
\hline Mo & - & - & - & - & - & - & - \\
\hline Total & 1,003 & 1,005 & 1,004 & 1,006 & 1,004 & 1,002 & 1,003 \\
\hline
\end{tabular}

$\mathrm{FeO}^{*}$ : as $\mathrm{FeO} ; \mathrm{Fe}^{*}$ : as $\mathrm{Fe}^{2+}$; < DL: below detection limit. 
hydrothermal deposits ( 100 to $300^{\circ} \mathrm{C}$ ), where $\mathrm{Al}$ levels were high and Ti was below the detection limit. According to Rusk et al. (2008), the $\mathrm{Al}$ content of hydrothermal quartz reflects its solubility in hydrothermal fluids, which is highly dependent on $\mathrm{pH}$. The $\mathrm{Al}$ and $\mathrm{Ti}$ concentrations in typically hydrothermal Qz4 from the Mocambo Granite is also similar to those reported in quartz crystals from vesicles in the greisens and veins of the Cinovec deposit (Czech Republic), which show significant $\mathrm{Al}$ enrichment and low Ti levels (Breiter et al.2017).

Variations in $\mathrm{Al}$ content seem to be more complex in the Mocambo Granite, since Qz4 is Al-rich while Qz3 and Qz5 are depleted in this element. The compositional similarities

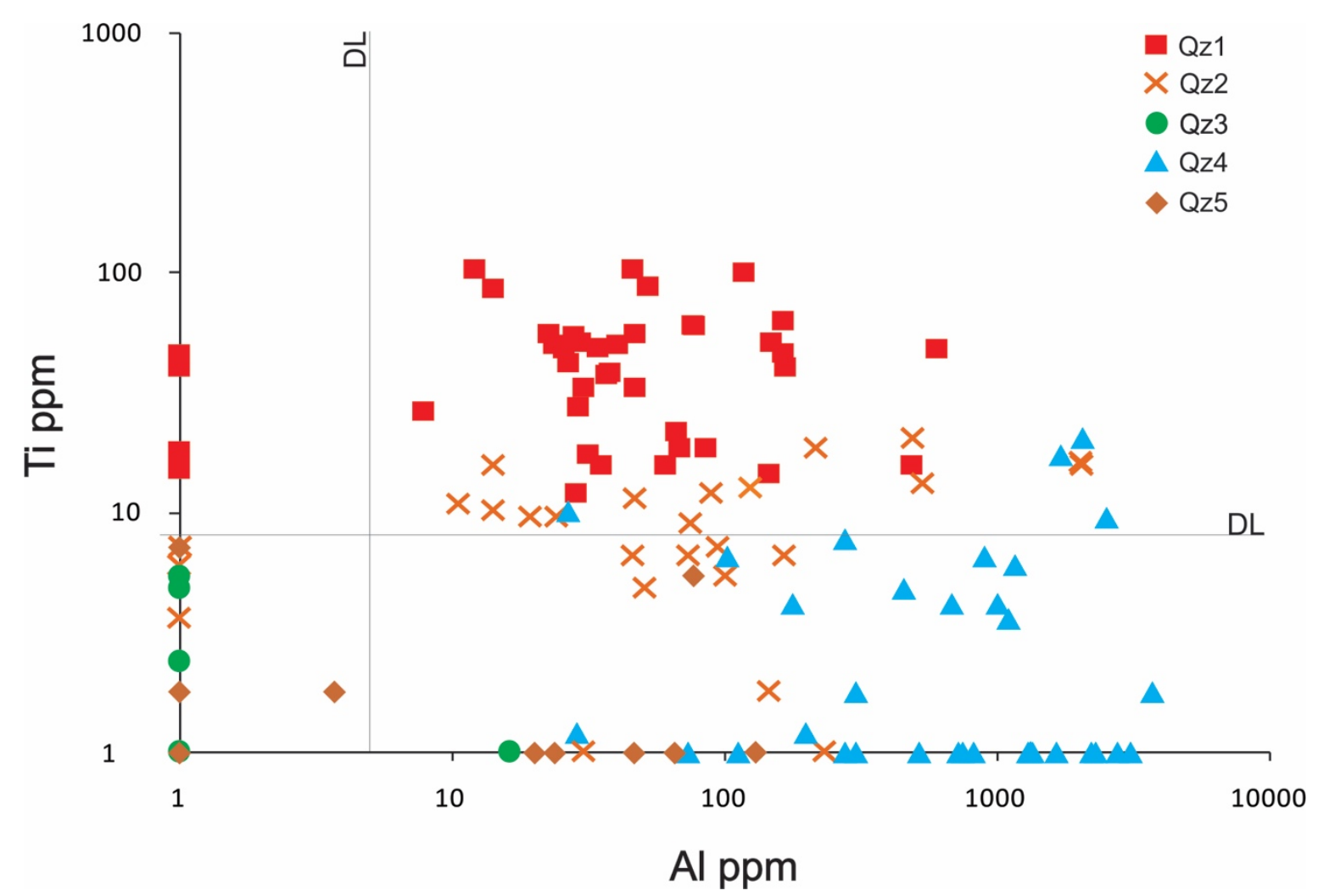

Figure 7. Ti vs. Al diagram showing the compositional variations on quartz types. The data below the detection limit (DL) are qualitative and only indicative of its presence in the mineral.
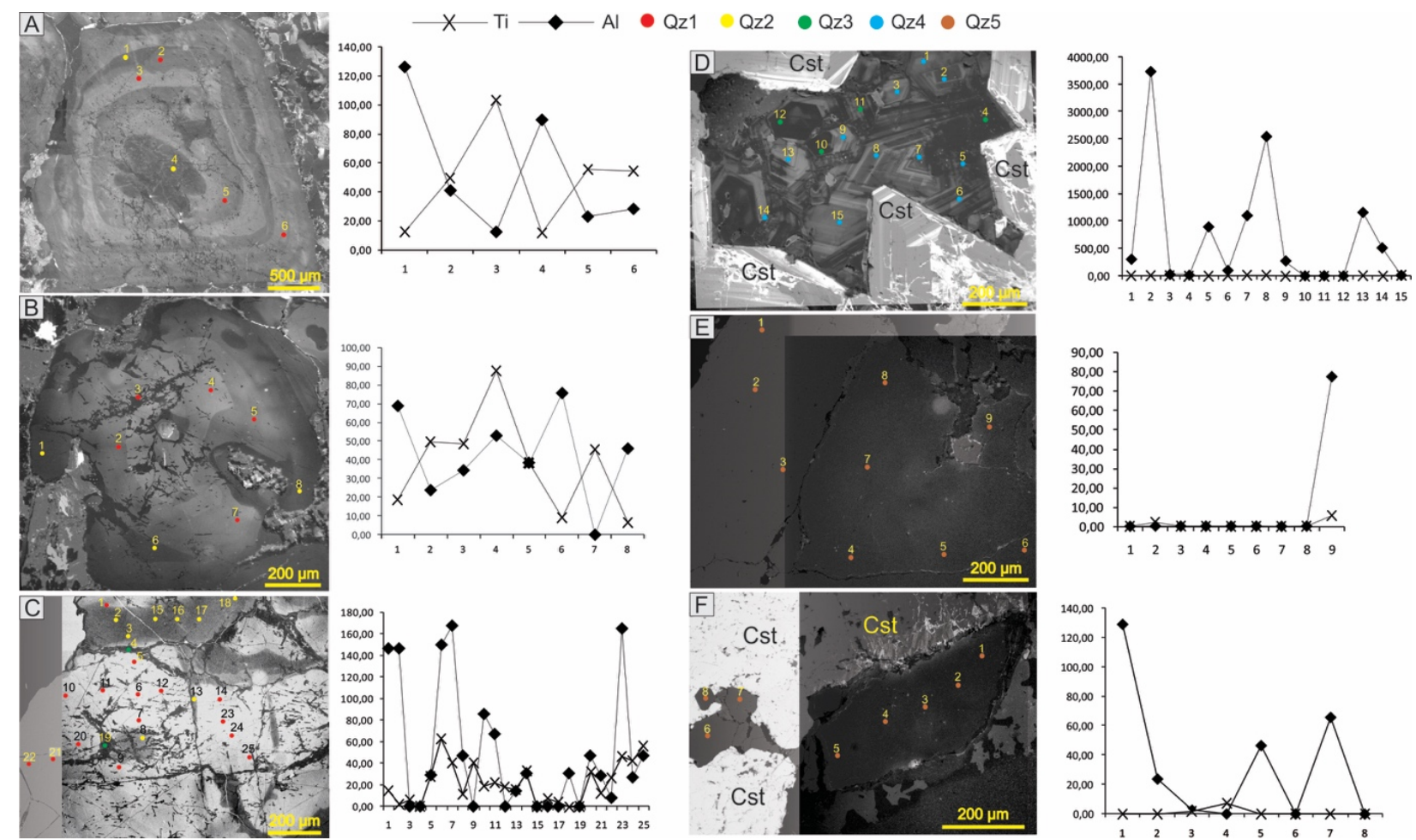

Figure 8. Cathodoluminescence images (A and B) and overlapping and backscattered electron (BSE) images (C, D, E and F) showing the relationship between the quartz types and their respective $\mathrm{Ti}$ and $\mathrm{Al}$ concentrations. 
between Qz3 and Qz5 suggest they may have been formed by chemically similar hydrothermal fluids.

\section{Compositional variation of cassiterite}

The values obtained are consistent with those found in zoned cassiterite from other deposits. The lighter zones are more Sn-rich than the darker zones (Costi et al. 2000, Souza and Botelho 2009). As reported by Möller et al. (1988), Neiva (1996), and Murciego et al. (1997), the entry of Fe, Ti, Nb, and $\mathrm{W}$ into the cassiterite structure can be summarized by the following equations: $2 \mathrm{Sn}^{4+}+\mathrm{O}^{2-} \leftrightarrow \mathrm{Ti}^{4+}+\mathrm{Fe}^{3+}+\mathrm{OH}^{-}$ and $3(\mathrm{Sn}, \mathrm{Ti})^{4+} \leftrightarrow 2(\mathrm{Nb}, \mathrm{Ta})^{5+}+\mathrm{Fe}^{2+}$, where the coupled
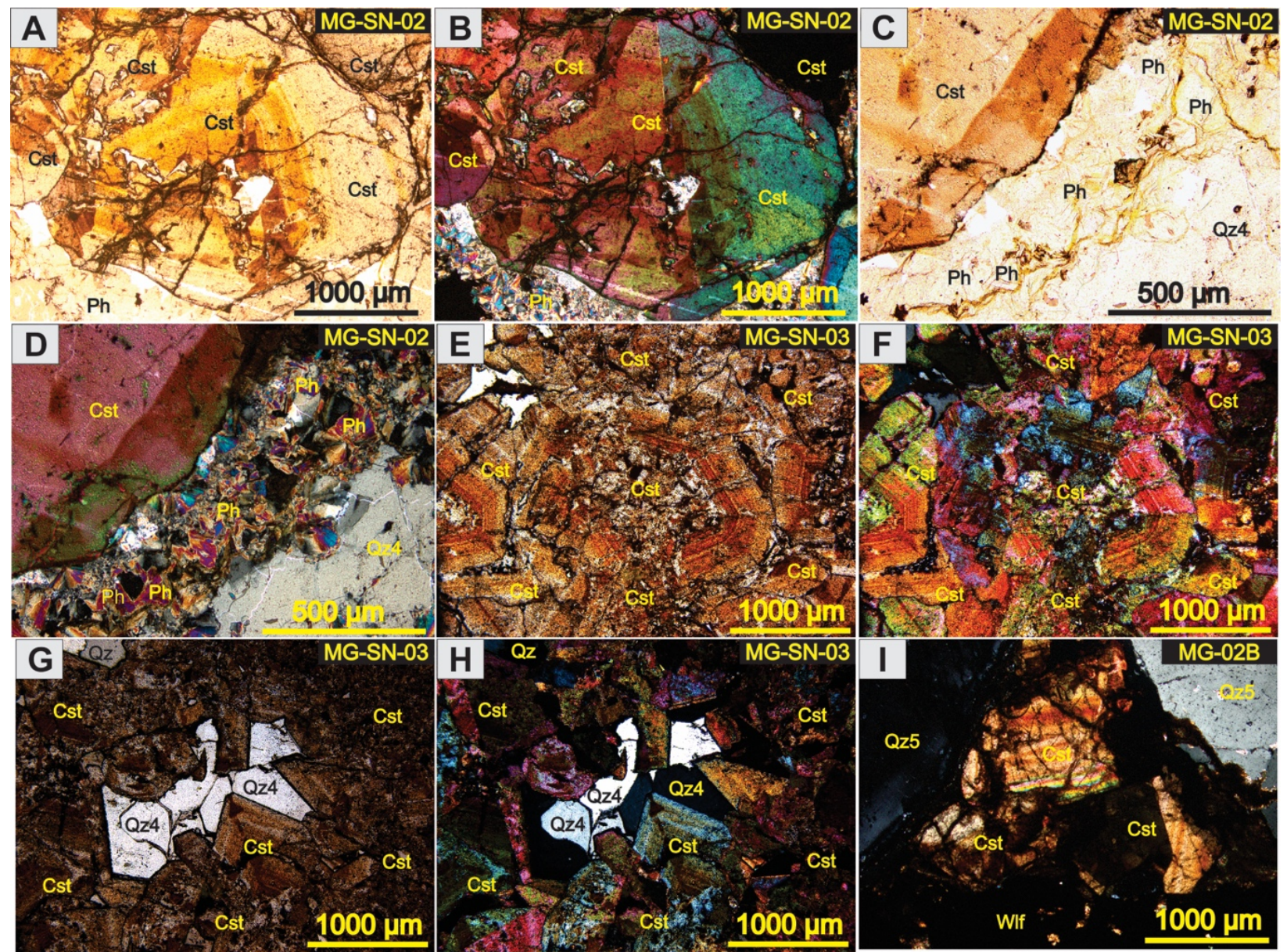

Figure 9. Textural aspects of cassiterite (Cst) under an optical microscope: (A, C, E and G) parallel polarizer; (B, D, F, H and I) crossed polarizer; (A and B) light brown, slightly zoned twinned crystals associated with phengite $(\mathrm{Ph})$; $(\mathrm{C}$ and $\mathrm{D})$ light brown cassiterite associated with phengite and Qz4; (E and F) dark brown, zoned cassiterite, with high interference colors; $(\mathrm{G}$ and $\mathrm{H})$ zoned cassiterite and interstitial Qz4; (I) Fractured and altered cassiterite associated with Qz5 and wolframite (Wlf).
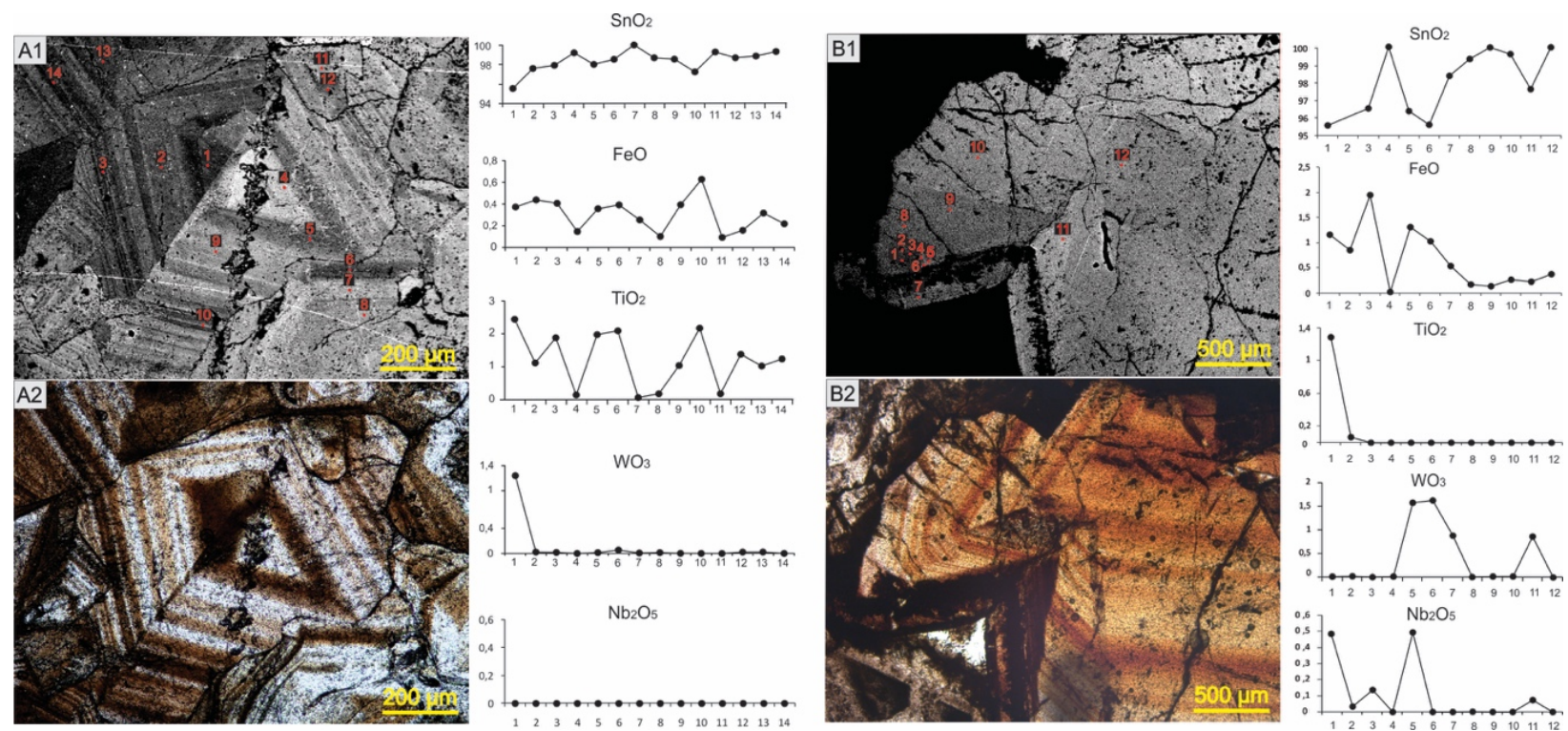

Figure 10. Electron microprobe analyses of cassiterite crystals: (A1 and B1) backscattered electron images showing the compositional variation of the different zones; (A2 and B2) parallel polarizer images. 


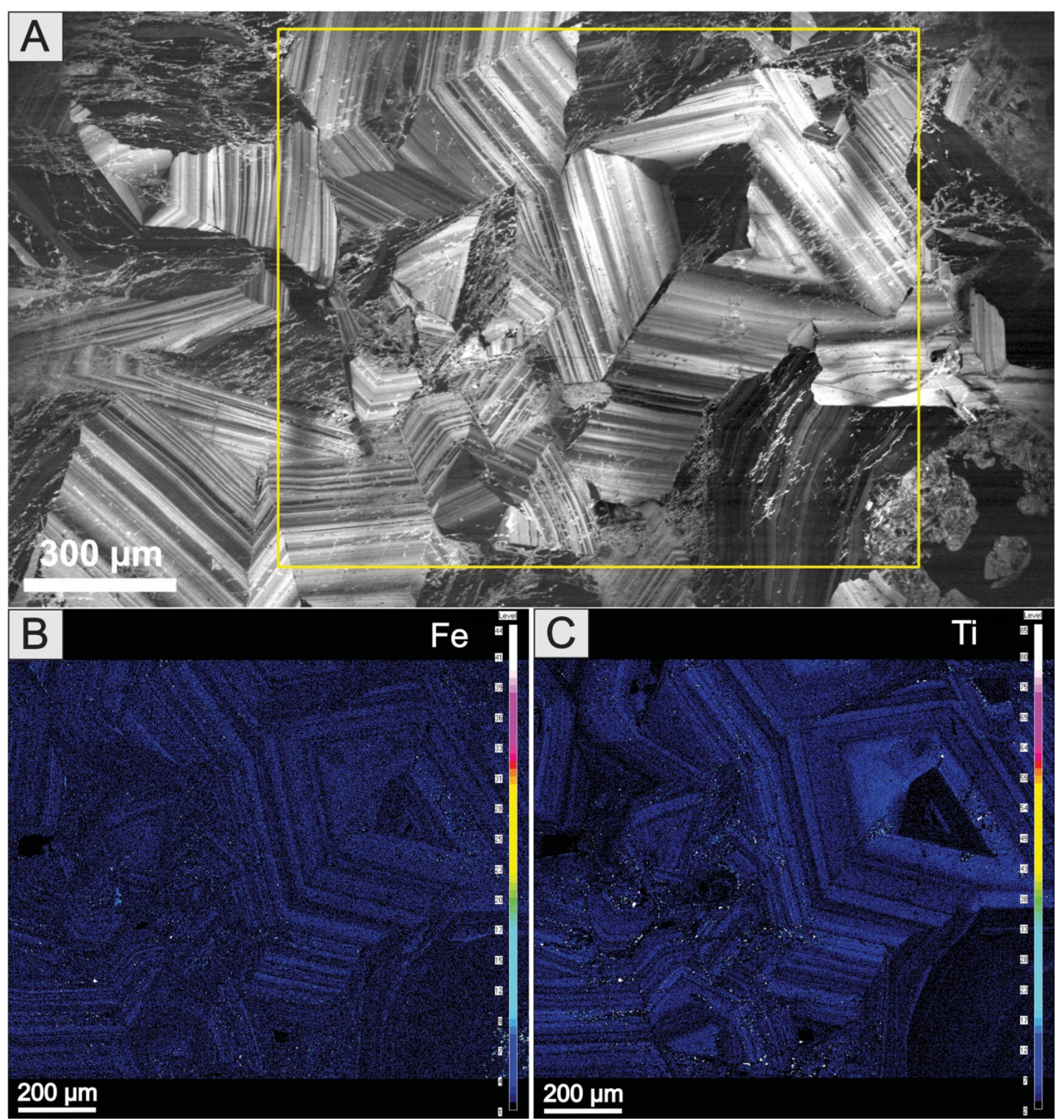

Figure 11. Qualitative compositional map of zoned cassiterite crystals: (A) CL image of cassiterite crystals with the mapped area outlined; (B) Compositional map for Fe; (C) compositional map for Ti. The light-colored zones are enriched and dark zones are depleted.

\section{Stage 1}

Magmatic unaltered Qz1 interacting with deuteric fluids and forming Qz 2 .

\section{Stage 2}

Dissolution and fracture of Qz1 forming Qz2 and Qz3.

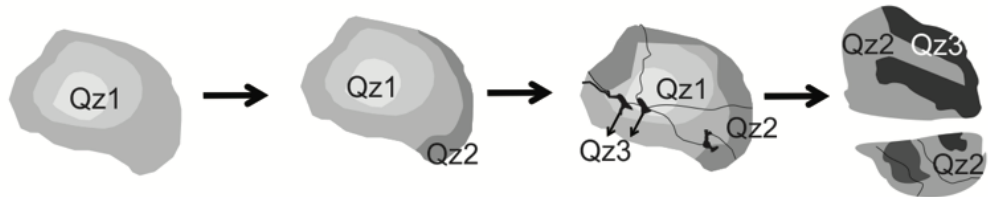

Stage 3

Recrystallization and formation of zoning Formation of Qz4

\section{Stage 4}

Continuous percolation of hydrothermal fluids, reacting with Qz4 to form Qz5

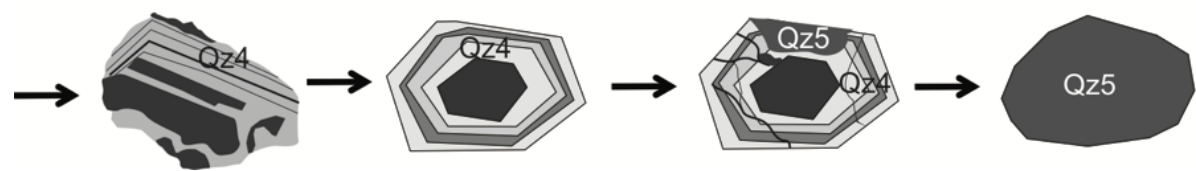

Figure 12. Schematic diagram of quartz evolution in CL images: (Stage 1) magmatic, strong luminescent Qz1 reacts with hydrothermal fluids and forms lower-luminescent Qz2, which typically occurs along the edges of Qz1; (Stage 2) dissolution and fracture of Qz1, with the fractures filled by low-luminescent, dark grey Qz3 and intense formation of Qz2 and Qz3; (Stage 3) continued hydrothermal alteration, recrystallization and formation of zoned Qz4 crystals; (Stage 4) continuous percolation of hydrothermal fluids, reacting with and consuming Qz4 to form dark grey, low luminescent Qz5. 
substitutions of $\mathrm{Sn}$ by $\mathrm{Fe}$ and $\mathrm{Ti}$, and $\mathrm{Sn}$ and $\mathrm{Ti}$ by $\mathrm{Nb}$ and $\mathrm{Ta}$ occur. In turn, W may participate in $\mathrm{Sn}$ and Fe substitution, forming molecular wolframite represented by the equation $2(\mathrm{Sn}, \mathrm{Ti})^{4+} \leftrightarrow \mathrm{W}^{6+}+\mathrm{Fe}^{2+}$.

Haapala (1997) and Costi et al. (2000) demonstrated the relationship between $\mathrm{Nb}_{2} \mathrm{O}_{5}, \mathrm{Ta}_{2} \mathrm{O}_{5}, \mathrm{FeO}$, and $\mathrm{TiO}_{2}$ concentrations and cassiterite formation, indicating that magmatic or high-temperature cassiterite is rich in $\mathrm{Nb}_{2} \mathrm{O}_{5}+\mathrm{Ta}_{2} \mathrm{O}_{5}$ and $\mathrm{FeO}$, whereas low-temperature hydrothermal cassiterite is $\mathrm{TiO}_{2}$ enriched.

Souza and Botelho (2009) studied the chemical composition and oxygen isotopes of cassiterite and wolframite from greisens of the Bom Futuro Sn deposit (Rondônia State, Brazil). The results showed that cassiterite contained $\mathrm{Sn}, \mathrm{Nb}, \mathrm{Ta}, \mathrm{Fe}$, $\mathrm{Ti}$, and $\mathrm{W}$; the isotope oxygen data demonstrated that both cassiterite and wolframite precipitated in magmatic hydrothermal fluid at 420 to $460^{\circ} \mathrm{C}$.

Cassiterite in the quartz veins and greisens of the Mocambo Granite showed fluctuating Ti, W and Fe levels, with low $\mathrm{Nb}$ content and Ta values below the limit of detection, suggesting that a magmatic origin is unlikely. Moreover, the slight $\mathrm{Ti}$ and $\mathrm{W}$ enrichment and association of cassiterite with both Qz4 and Qz5 indicates a hydrothermal origin for cassiterite.

\section{CONCLUSIONS}

The Mocambo Granite experienced late to post-magmatic high-temperature interaction with volatile-rich residual fluids. Morphological and compositional analyses demonstrated that quartz is an excellent marker of the magmatic evolution and alteration caused by the hydrothermal process that affected the MG, where one magmatic ( $\mathrm{Q} 1)$ and four hydrothermal generations of quartz (Qz2, Qz3 Qz4 and Qz5) were identified.

The highest Ti concentrations were observed in Qz1, particularly in less evolved rocks.

Titanium content declined to below the limit of detection in Qz3, Qz4, and Qz5 as the alteration processes intensified.
Aluminium concentrations varied in the early quartz types (Qz1 and Qz2), with the lowest values found in Qz3 and Qz5 and considerable enrichment in Qz4, present in the interstices of cassiterite concentrates in GR.

CL images indicate that tin mineralization occurs in the most evolved and hydrothermally altered rocks, such as GR and quartz veins, where cassiterite is associated with Qz4 or Qz5 + wolframite. The images of Qz5 suggest the presence of a mineralizing hydrothermal event in wolframite after the event that gave rise to the cassiterite, predominantly associated with Qz4.

In addition to $\mathrm{Sn}$, cassiterites exhibited lower $\mathrm{Fe}, \mathrm{Ti}, \mathrm{W}$, and $\mathrm{Nb}$ concentrations and trace amounts of $\mathrm{Mn}$; $\mathrm{Ta}$ was below the detection limit. $\mathrm{Fe}, \mathrm{Nb}, \mathrm{Ti}$, and $\mathrm{W}$ contents were higher in the dark zones, whereas $S n$ content was highest in the lightest parts of the crystals. $\mathrm{Fe}, \mathrm{Nb}, \mathrm{Ti}$, and $\mathrm{W}$ replaced $\mathrm{Sn}$ and entered the cassiterite structure through coupled substitutions.

Cassiterites associated with Qz5 often occur as inclusions in wolframite crystals, reinforcing the hypothesis that wolframite precipitation likely occurred through later hydrothermal processes than those that formed cassiterite.

\section{ACKNOWLEDGMENTS}

The authors are grateful to the reviewers and regional editor for their comments and suggestions, the Conselho Nacional de Desenvolvimento Científico e Tecnológico ( $\mathrm{CNPq}$ ) for the master's scholarship awarded to the first author and the PQ-2 CNL research grant (Process 305701/2014-2) for the second author. This study was financed in part by the Coordenação de Aperfeiçoamento de Pessoal de Nivel Superior - Brasil (CAPES) Finance Code 001, the Instituto de Geociencias of UFPA, and the Grupo de Pesquisa Petrologia de Granitoides (GPPG). This study is a contribution to the MCTI/CNPQ/Universal Research Project (Process 458941/2014-0) and the Instituto de Geociências da Amazônia - GEOCIAM (INCT-CNPq/ MCT/FAPESPA-Proc. 573733/2008-2).

\section{ARTICLE INFORMATION}

Manuscript ID: 20190096. Received on: 07/13/2019. Approved on: 07/13/2020.

R.N. wrote the first draft of the manuscript, prepared all figures, revised, and improved the manuscript; C.L. revised and improved the manuscript through corrections, discussions and suggestions; G.M. provided EPM data and cathodoluminescence images, and improved the manuscript; C.C. revised and improved the manuscript.

Competing interests: The authors declare no competing interests.

\section{REFERENCES}

Abreu F.A.M., Ramos C.R. 1974. Estanho do Sul do Pará. In: Congresso Brasileiro de Geologia, 28., Porto Alegre. Anais..., 5, p. 11-23. SBG.

Almeida F.F.M., Hasui Y., De Brito Neves B.B., Fuck R.A. 1981. Brazilian Structural Provinces: an introduction. Earth-Science Review, 17(1-2):1-29. https://doi.org/10.1016/0012-8252(81)90003-9

Almeida J.A.C., Dall'Agnol R., Oliveira D.C. 2006. Geologia petrografia e geoquímica do Granito anorogênico Bannach, Terreno Granito-Greenstone de Rio Maria, Pará. Revista Brasileira de Geociências, 36(2):282-295.
Breiter K., Ackerman L., Svojtka M., Müller A. 2013. Behavior of trace elements in quartz from plutons of different geochemical signature: A case study from the Bohemian Massif, Czech Republic. Lithos, 175-176:54-67. https://doi.org/10.1016/j.lithos.2013.04.023

Breiter K., Ďurišová J., Dosbaba M. 2017. Quartz chemistry - A step to understanding magmatic-hydrothermal processes in ore-bearing granites: Cínovec/Zinnwald Sn-W-Li deposit, Central Europe. Ore Geology Reviews, 90:25-35. https://doi.org/10.1016/j.oregeorev.2017.10.013 
Breiter K., Müller A. 2009. Evolution of rare-metal granitic magmas documented by quartz chemistry. European Journal of Mineralogy, 21(2):335-346. https://dx.doi.org/10.1127/0935-1221/2009/0021-1907

Companhia de Pesquisa de Recursos Minerais (CPRM)/Departamento Nacional de Produção Mineral (DNPM). 1997. Programa levantamentos geológicos básicos do Brasil. São Félix do Xingu. Folha SB-22-Y-B. Estado do Pará. Brasília: CPRM/DNPM, 344 p.

Costi H.T., Horbe M.A.C., Borges R.M.K, Dall’Agnol R., Rossi A., Sighnolfi G. 2000. Mineral chemistry of cassiterites from Pitinga Province, Amazonian Craton, Brazil. Revista Brasileira de Geociências, 30(4):775-782.

Dall'Agnol R. 1980. Etudes sur des granites du type "Rondonian" em Amazonie Orientale et leurs transformations tardi-magmatiques. These Troisieme Cycle, Laboratoire de Geologie, Université, Paul Sabatier, Tolouse, 348 p.

Dall'Agnol R., Oliveira M.A., Almeida J.A.C., Althoff FJ., Leite A.A.S., Oliveira D.C., Barros C.E.M. 2006. Arquean and Paleoproterozoic granitoids of the Carajás Metallogenic Province, eastern Amazonian Craton. In: Symposium on Magmatism, Crustal evolution, and Metallogenesis of the Amazonian Craton. Belém: PRONEX-UFPA/SBG-NO, p. 97-150.

Dall'Agnol R., Teixeira N.P., Magalhães M.S. 1993. Diagnostic features of the Tin-specialized anorogenic granites of the Eastern Amazonian Region. Anais da Academia Brasileira de Ciências, 65(1):33-50.

Dall'Agnol R., Teixeira N.P., Ramo O.T., Moura C.A.V., Macambira M.J.B., Oliveira D.C. 2005. Petrogenesis of the paleoproterozoic rapakivi A-type granites of the Archean Carajás Metallogenic Province, Brazil. Lithos, 80(14):101-129. https://doi.org/10.1016/j.lithos.2004.03.058

D’Lemos R.S., Kearsley A.T., Pembroke J.W., Watt G.R., Wright P. 1997. Complex quartz growth histories in granite revealed by scanning cathodoluminescence techniques. Geological Magazine, 134(4):549-552. https://doi.org/10.1017/S0016756897007280

Eby G.N. 1992. Chemical subdivision of the A-type granitoids: petrogenetic and tectonic implications. Geology, 20(7):641-644. https://doi. org/10.1130/0091-7613(1992)020\%3C0641:CSOTAT\%3E2.3.CO;2

Haapala I. 1997. Magmatic and post-magmatic processes in tin-mineralized granites: topaz-bearing leucogranite in the Eurajoki Rapakivi Granite stock, Finland. Journal of Petrology, 38(12):1645-1659. https://doi.org/10.1093/ petroj/38.12.1645

Jacamon F., Larsen R.B. 2009. Trace element evolution of quartz in the charnockitic Kleivan granite, SW-Norway: The Ge/Ti ratio of quartz as an index of igneous differentiation. Lithos, 107(3-4):281-291. https://doi. org/10.1016/j.lithos.2008.10.016

Juliani C., Fernandes C.M.D. 2010. Well-preserved late paleoproterozoic volcanic centers in the São Felix do Xingu region, Amazonian Craton, Brazil. Journal of Volcanology and Geothermal Research, 191(3-4):167-179. https:// doi.org/10.1016/j.jvolgeores.2010.01.016

Lamarão C.N., Borges R.M.K., Marques G.T. 2014. Catodoluminescência em cristais de quartzo: implicações petrológicas e metalogenéticas. Boletim do Museu Paraense Emílio Goeldi. Ciências Naturais, 9(1):73-91.

Lamarão C.N., Pinho S.C.C., Paiva Junior A.L., Galarza M.A. 2012. Mineralogy and geochemistry of the Paleoproterozoic, tin-mineralized Bom Jardim Granite of the Velho Guilherme Suite, eastern Amazonian Craton. Journal of South American Earth Science, 38:159-173. https://doi. org/10.1016/j.jsames.2012.05.004

Lamarão C.N., Rocha K.K.N., Marques G.T., Borges R.M.K. 2013. Quartzo e zircão como marcadores da evolução magmático hidrotermal do Granito Antônio Vicente, Suíte Intrusiva Velho Guilherme, Província Carajás. Geologia USP. Série Científica, 13(2):49-68. https://doi.org/10.5327/Z1519-874X2013000200004

Larsen R.B., Jacamon F., Kronz A. 2009. Trace element chemistry and textures of quartz during the magmatic hydrothermal transition of Oslo Rift granites. Mineralogical Magazine, 73(4):691-707. https://doi.org/10.1180/ minmag.2009.073.4.691

Möller P., Dulski P., Szacki W., Malow G., Riedel E. 1988. Substitution of tin in cassiterite by tantalum, niobium, tungsten, iron and manganese. Geochimica et Cosmochimica Acta, 52(6):1497-1503. https://doi. org/10.1016/0016-7037(88)90220-7

Müller A., Breiter K., Seltmann R, Pécskay Z. 2005. Quartz and feldspar zoning in the eastern Erzgebirge volcano-plutonic complex (Germany, Czech Republic): evidence of multiple magma mixing. Lithos, 80(1-4):201227. https://doi.org/10.1016/j.lithos.2004.05.011
Müller A., Herklotz G., Giegling H. 2018. Chemistry of quartz related to the Zinnwald/Cínovec Sn-W-Li greisen-type deposit, Eastern Erzgebirge, Germany. Journal of Geochemical Exploration, 190:357-373. https://doi. org/10.1016/j.gexplo.2018.04.009

Müller A., Kronz A., Breiter K. 2002. Trace elements and growth patterns in quartz: a fingerprint of the evolution of the subvolcanic Podlesí Granite System (Krušné hory Mts., Czech Republic). Bulletin of the Czech Geological Survey, 77(2):135-145

Müller A., René M., Behr HJ., Kronz A. 2003. Trace elements and cathodoluminescence in igneous quartz in topaz granites from the Hub Stock (Slavkovský Les Mts., Czech republic). Mineralogy and Petrology, 79:167-191. https://doi.org/10.1007/s00710-003-0238-3

Müller A., Seltmann R., Behr H.J. 2000. Application of cathodoluminescence to magmatic quartz in a tin granite-case study from the Schellerhau granite Complex, Eastern Erzgebirge, Germany. Mineralium Deposita, 35:169-189. https://doi.org/10.1007/s001260050014

Murciego A., Sanchez A.G., Dusausoy Y., Pozas J.M.M., Ruck R. 1997. Geochemistry and EPR of cassiterites from the Iberian Hercynian Massif. Mineralogical Magazine, 61(3):357-365

Neiva A.M.R. 1996. Geochemistry of cassiterite and its inclusions and exsolutions products from tin and tungsten deposits in Portugal. Canadian Mineralogist, 34(4):745-768.

Pinho S.C.C., Fernandes C.M.D., Teixeira N.P., Paiva Junior A.L., Cruz V.L., Lamarão C.N., Moura C.A.V. 2006. O magmatismo paleoproterozóico da região de São Felix do Xingu, Província Estanífera do Sul do Pará: Petrografia e geocronologia. Revista Brasileira de Geociências, 36(4):793-802.

Rusk B.G., Lowers H.A., Reed M.H. 2008. Trace elements in hydrothermal quartz: Relationships to cathodoluminescent textures and insights into vein formation. Geology, 36(7):547-550. https://doi. org/10.1130/G24580A.1

Rusk B.G., Reed M.H. 2002. Scanning electron microscope cathodoluminescence analysis of quartz reveals complex growth histories in veins from the Butte porphyry copper deposit, Montana. Geology, 30(8):727-730. https://doi.org/10.1130/0091-7613(2002)030\%3C0727 :SEMCAO\%3E2.0.CO;2

Rusk B.G., Reed M.H., Dilles J.H., Kent A.J.R. 2006. Intensity of quartz cathodoluminescence and trace-element content in quartz from the porphyry copper deposit at Butte, Montana. American Mineralogist, 91(89):1300-1312. https://doi.org/10.2138/am.2006.1984

Santos J.O.S. 2003. Geotectônica dos escudos da Guiana e Brasil Central. In Bizzi LA., Schobbenhaus C., Vidotti RM., Gonçalves JH. (Eds.). Geologia, tectônica e recursos minerais do Brasil. Texto, mapas e SIG. Brasília: CPRM p. $169-226$.

Sotero A.M., Lamarão C.N., Marques G.T., Rodrigues P.R.S. 2015 Quartzo magmático e hidrotermal do depósito de ouro São Jorge, Província Aurífera do Tapajós, Pará: petrografia, microscopia eletrônica de varredura-catodoluminescência e implicações metalogenéticas. Brazilian Journal of Geology, 45(4):591-607. http://dx.doi. org/10.1590/2317-4889201520150011

Souza V.S., Botelho N.F. 2009. Composição química e isótopos de oxigênio em cassiterita e wolframita nos greisens do albita granito Palanqueta, depósito de estanho de Bom Futuro (RO). Revista Brasileira de Geociências, 39(4):695-704

Streckeisen A. 1976. To each plutonic rocks its proper name. Earth Science Reviews, 12(1):1-33. https://doi.org/10.1016/0012-8252(76)90052-0

Teixeira N.P. 1999. Contribuição ao estudo das rochas granitoides e mineralizações associadas da Suite Intrusiva Velho Guilherme, Província Estanifera do Sul do Pará. Tese de Doutorado, Instituto de Geociências, Universidade de São Paulo, São Paulo, 508 p.

Teixeira N.P., Bettencourt J.S., Dall'Agnol R., Moura C.A.V., Fernandes C.M.D., Pinho S.C.C. 2005. Geoquímica dos granitos paleoproterozóicos da Suíte Granítica Velho Guilherme, Província Estanífera do Sul do Pará Revista Brasileira de Geociências, 35(2):217-226.

Teixeira N.P., Bettencourt J.S., Moura C.A.V., Dall'Agnol R., Macambira E.M.B. 2002. Archean crustal sources for paleoproterozoic tin granites in the Carajás Province, SSE Pará, Brazil: $\mathrm{Pb}-\mathrm{Pb}$ geochronology and $\mathrm{Nd}$ isotope geochemistry. Precambrian Research, 119(1-4):257-275. 
Teixeira N.P., Dall'Agnol R. 1991. Geologia e petrografia do maciço granítico Antônio Vicente, região de São Félix do Xingu/PA. Boletim do Museu Paraense Emílio Goeldi. Série Ciências da Terra, 3:45-73.

Vasquez M.L., Rosa-Costa L.T., Silva C.M.G., Ricci P.S.F., Barbosa J.P.O., Klein E.L., Lopes E.C.S., Macambira E.M.B., Chaves C.L., Carvalho J.M.A., Oliveira J.G.F., Anjos G.C., Silva H.R. 2008. Unidades Litoestratigráficas. In: Vasquez M.L., Rosa-Costa L.T. (Eds.). Geologia e Recursos Minerais do Estado do Pará. Sistema de Informações Geográficas - SIG: texto explicativo dos mapas Geológico e Tectônico e de Recursos Minerais do Estado do Pará. Escala 1:1.000.000. Belém: CPRM.

Vasyukova O.V., Kamenetsky V.S., Goemann K., Davidson P. 2013. Diversity of primary CL textures in quartz from porphyry environments: implication for origin of quartz eyes. Contributions to Mineralogy and Petrology, 166:1253-1268. https://doi.org/10.1007/s00410-013-0923-0
Wark D.A, Watson E.B. 2006. TitaniQ: a titanium-in-quartz geothermometer. Contributions to Mineralogy and Petrology, 152:743-754. https://doi.org/10.1007/s00410-006-0132-1

Whalen J.B., Currie K.L., Chappell B.W. 1987. A-type granites: geochemical characteristics, discrimination and petrogenesis. Contributions to Mineralogy and Petrology, 95:407-419. https://doi.org/10.1007/BF00402202

Whitney D.L., Evans B.W. 2010. Abbreviations for names of rock-forming minerals. American Mineralogist, 95(1):185-187. https://doi.org/10.2138/ am.2010.3371

Wiebe R.A., Wark D.A., Hawkins D.P. 2007. Insights from quartz cathodoluminescence zoning into crystallization of the Vinalhaven granite, coastal Maine. Contributions to Mineralogy and Petrology, 154:439-453. https://doi.org/10.1007/s00410-007-0202-z 